ISSN (print): 1698-6180. ISSN (online): 1886-7995

www.ucm.es/info/estratig/journal.htm

Journal of Iberian Geology 36 (2) 2010: 205-224

doi:10.5209/rev_JIGE.2010.v36.n2.8

\title{
La Cantalera: an exceptional window onto the vertebrate biodiversity of the Hauterivian-Barremian transition in the Iberian Peninsula
}

\author{
La Cantalera: una excepcional ventana a la biodiversidad del tránsito \\ Hauteriviense- Barremiense en la Península Ibérica
}

\begin{abstract}
J.I. Canudo ${ }^{1}$, J.M. Gasca ${ }^{1}$, M. Aurell ${ }^{2}$, A. Badiola ${ }^{1}$, H.-A. Blain ${ }^{3}$, P. Cruzado-Caballero ${ }^{1}$, D. GómezFernández $^{1}$, M. Moreno-Azanza ${ }^{1}$, J. Parrilla ${ }^{1}$, R. Rabal-Garcés ${ }^{1}$, J. I. Ruiz-Omeñaca ${ }^{1,4}$

${ }^{1}$ Grupo Aragosaurus (http://www.aragosaurus.com). Universidad de Zaragoza. 50009 Zaragoza, Spain. jicanudo@unizar.es,gascajm@unizar.es,abadiola@unizar.es,penelope@unizar.es, danielgomezfdez@gmail.com,mmazanza@unizar.es,rrabal@unizar.es

${ }^{2}$ Estratigrafía.Universidad de Zaragoza.50009Zaragoza.Spain.maurell@unizar.es

${ }^{3}$ Institut Català de Paleoecologia Humana y Evolució Social (Unitat asociada al CSIC).

Universitat Rovira i Virgili.43005 Tarragona.Spain.hablain@prehistoria.urv.cat

${ }^{4}$ Museo del Jurásico de Asturias (MUJA). 33328 Colunga. Asturias. Spain.
\end{abstract}

jigruiz@unizar.es

Received: 15/11/09 / Accepted: 30/06/10

\begin{abstract}
La Cantalera is an accumulation site for fossil vertebrates consisting mainly of teeth and isolated postcranial remains. It has the greatest vertebrate biodiversity of any site from the Hauterivian-Barremian transition in the Iberian Peninsula. Up to now, 31 vertebrate taxa have been recognized: an osteichthyan (Teleostei indet.), two amphibians (Albanerpetonidae indet. and Discoglossidae indet.), a chelonian (Pleurosternidae? indet.), a lizard (Paramacellodidae? indet.), four crocodylomorphs (cf. Theriosuchus sp., Bernissartiidae indet., Goniopholididae indet., cf. Lisboasaurus sp.), two pterosaurs (Istiodactylidae? indet., Ornithocheiridae? indet.), four ornithopod dinosaurs (Iguanodontoidea indet., Hadrosauroidea? indet., "Hypsilophodontidae" indet., Rhabdodontidae? indet.), a thyreophoran (Polacanthidae indet.), a sauropod (Euhelopodidae indet.), eleven theropods (Carcharodontosauridae? indet., Baryonychinae indet., aff. Paronychodon sp., Maniraptora indet. 1-3, Dromaeosaurinae indet. 1-3, Velociraptorinae indet., Avialae? indet.) and three or four multituberculate mammals (Cantalera abadi, Eobaatar sp., Plagiaulacidae or Eobaataridae gen. et sp. indet., "Plagiaulacida" indet.). Nine ootaxa have also been distinguished at the site of La Cantalera. Oofamilies assigned to dinosaurs (Elongaloolithidae, Prismatoolithidae, cf. Spheroolithidae), to crocodiles (Krokolithidae) and eggshells of two oofamilies
\end{abstract}


incertidae sedis are represented. This association is consistent with the record of bone and tooth remains from the site. La Cantalera was formed in a marshy environment where there was an intermittent body of water. The great majority of the vertebrate fossil remains lack evidence of transport, so the preserved association is a good representation of the vertebrate ecosystem in or around the marshy area of La Cantalera. The vertebrate association of La Cantalera displays certain differences with respect to those from lacustrine environments of the Hauterivian-Barremian transition of the Iberian Range. These differences include, for example, the absence of Chondrichthyes, the merely token presence of the osteichthyans, the scarcity of chelonians, the presence of exclusively multituberculate mammals, the lower diversity of sauropods and the greater diversity of theropods.

Keywords: Vertebrata, Biodiversity, Iberian Range, Hauterivian-Barremian, Spain

\section{Resumen}

La Cantalera es un yacimiento de acumulación de vertebrados fósiles compuesto mayoritariamente por dientes y restos postcraneales aislados. Se trata del yacimiento con mayor biodiversidad de vertebrados en el tránsito Hauteriviense-Barremiense en la Península ibérica. Hasta el momento se han reconocido 31 taxones de vertebrados: un actinopterigio (Teleostei indet.), dos anfibios (Albanerpetonidae indet. y Discoglossidae indet.), un quelonio (Pleurosternidae? indet.), un lagarto (Paramacellodidae? indet.), cuatro crocodilomorfos (cf. Theriosuchus sp., Bernissartiidae indet., Goniopholididae indet., cf. Lisboasaurus sp.), dos pterosaurios (Istiodactylidae? indet., Ornithocheiridae? indet.), cuatro dinosaurios ornitópodos (Iguanodontoidea indet., Hadrosauroidea? indet., "Hypsilophodontidae" indet., Rhabdodontidae? indet.), un tireóforo (Polacanthidae indet.), un saurópodo (Euhelopodidae indet.), once terópodos (Carcharodontosauridae? indet., Baryonychinae indet., aff. Paronychodon sp., Maniraptora indet. 1-3, Dromaeosaurinae indet. 1-3, Velociraptorinae indet. y Avialae? indet.) y tres o cuatro mamíferos multibuberculados (Cantalera abadi, Eobaatar sp., Plagiaulacidae or Eobaataridae gen. et sp. indet., "Plagiaulacida" indet.). También se han diferenciado nueve ootaxones. Están representadas oofamilias asignadas a dinosaurios (Elongaloolithidae, Prismatoolithidae, cf. Spheroolithidae), a cocodrilos (Krokolithidae) y a dos oofamilias incertidae sedis. Esta asociación es coherente con el registro de restos directos del yacimiento. La Cantalera se formó en un medio palustre donde se desarrollo una lámina de agua intermitente. La gran mayoría de los restos fósiles de vertebrados carecen de evidencias de transporte, por lo que la asociación conservada es una buena representación del ecosistema de vertebrados que vivían en o cerca del área palustre de La Cantalera. La asociación de los vertebrados de La Cantalera presenta algunas diferencias con las de medios lacustres de la transición Hauteriviense-Barremiense de la Cordillera Ibérica. Entre estas diferencias se puede apuntar la ausencia de condrictios, la presencia meramente testimonial de los actinopterigios, escasez de quelonios, presencia exclusivamente de mamíferos multituberculados, menor diversidad de saurópodos y mayor diversidad de terópodos

Palabras clave: Vertebrados, Biodiversidad, Cordillera Ibérica, Hauteriviense-Barremiense, España

\section{Introduction}

Discoveries of dinosaur fossil remains from the Early Cretaceous sequence of Spain have increased notably in recent years, though these have in general been fragmentary and difficult to identify to a species level (Ruiz-Omeñaca et al., 2004; Ortega et al., 2006). In exceptional cases reasonably complete specimens have been recovered, making it possible to describe new taxa (Pérez-Moreno et al., 1994; Canudo et al., 2008b). These spectacular discoveries provide us with valuable systematic and palaeobiogeographical information (Pereda-Suberbiola et al., 2003; Canudo et al., 2009), yet in terms of learning about the palaeobiodiversity of the ecosystems they only yield sporadic data. Of greater interest in this respect are sites with an accumulation of different taxa with little transportation of the fossils, which can give us a rough idea of the minimal biodiversity of the vertebrates that lived in the ecosystem where the site or its environment was formed. At present, there are only sporadic studies of these accumulation sites in the Early Cretaceous of the Iberian Peninsula (Estes and Sanchiz, 1982b; Rauhut, 2002; Cuenca-Bescós and Canudo, 2003; Ruiz-Omeñaca et al., 2004; Buscalioni et al., 2008).

One of the sites where there is an extraordinary and diverse accumulation of macro- and micro-vertebrate remains from the Early Cretaceous is La Cantalera. Our team has been working there for more than ten years, recovering fossil material from surface prospections after periods of rain and from occasional excavations, and screen-washing some 3 tonnes of sediment. The sieve used has a $0.5 \mathrm{~mm}$ mesh. In addition, $20 \mathrm{~kg}$ of sediment have been screen-washed using a $0.150-\mathrm{mm}$ mesh in order to obtain a representative sample of microfossils other than vertebrates. As far as vertebrates are concerned, the fossil bone material consists mainly of isolated teeth, as well as disarticulated postcranial material (RuizOmeñaca et al., 1997). Also abundant are the eggshells recovered in the process of screen-washing (MorenoAzanza et al., 2009b), which were gathered from the fraction greater than $0.5 \mathrm{~mm}$ in size. The fraction between 0.150 and $0.5 \mathrm{~mm}$ includes eggshell fragments that have not been studied on account of their small size. 


\begin{tabular}{|c|c|c|c|}
\hline Class & Order & Sub/Infraorder & Taxa \\
\hline Osteichtyes & & & Teleostei indet. \\
\hline \multirow[t]{2}{*}{ Lissamphibia } & & & Albanerpetonidae indet. \\
\hline & Anura & & Discoglossidae indet. \\
\hline \multirow[t]{22}{*}{ "Reptilia" } & Chelonia & & Pleurosternidae? indet. \\
\hline & Squamata & Lacertilia & Paramacellodidae? indet. \\
\hline & Crocodylia & & $\begin{array}{l}\text { cf. Theriosuchus sp, } \\
\text { Bernissartiidae indet. } \\
\text { Goniopholididae indet. } \\
\text { cf. Lisboasaurus sp. }\end{array}$ \\
\hline & Pterosauria & & Istiodactylidae? Indet. \\
\hline & & & Ornithocheiridae? indet. \\
\hline & Ornithischia & Ornithopoda & Iguanodontoidea indet. \\
\hline & & & Hadrosauroidea? indet. \\
\hline & & & "Hypsilophodontidae" indet. \\
\hline & & & Rhabdodontidae? indet. \\
\hline & Thyreophora & & Polacanthidae indet. \\
\hline & Saurischia & Sauropoda & Euhelopodidae indet \\
\hline & & Theropoda & Baryonychinae indet. \\
\hline & & & Carcharodontosauridae? indet. \\
\hline & & & aff. Paronychodon sp. \\
\hline & & & Maniraptora indet. 1 \\
\hline & & & Maniraptora indet. 2 \\
\hline & & & Maniraptora indet. 3 \\
\hline & & & Dromaeosaurinae indet. 1 \\
\hline & & & Dromaeosaurinae indet. 2 \\
\hline & & & Dromaeosaurinae indet. 3 \\
\hline & & & Velociraptorinae indet. \\
\hline & & & Avialae? indet. \\
\hline \multirow[t]{4}{*}{ Mammalia } & Multituberculata & & Cantalera abadi Badiola et al. 2008 \\
\hline & & & Eobaatar sp. \\
\hline & & & "Plagiaulacida" indet. \\
\hline & & & Plagiaulacidae / Eobaataridae indet. \\
\hline
\end{tabular}

Table 1.- Vertebrate faunal list of La Cantalera (Josa, Teruel, Spain), late Hauterivian - early Barremian.

Tabla 1.- Lista faunística de los vertebrados del yacimiento de La Cantalera (Josa, Teruel, España), Hauteriviense superior - Barremiense inferior.

The state of preservation of the fossil remains is very variable, ranging from a semi-articulated series from an ornithopod to complete postcranial remains, shed teeth and functional teeth without evidence of transport. Yet there is also an abundance of unidentifiable splinters, with and without signs of transport. Bony fragments with evidence of transport are scarce. These differences in preservation are the result of the site's great taphonomic complexity, with biogenic and geological factors contributing to the accumulation. Some of the singular aspects of this accumulation have already been considered, such as the remarkable abundance of shed ornithopod teeth. Ruiz-Omeñaca et al. (1997) thus interpret La Cantalera as a feeding area for ornithopods, and the abundance as the result of the loss and replacement of teeth worn out by plant abrasion and tooth-to-tooth contact.

The teeth of some groups have been studied in depth, such as those of the sauropods (Canudo et al., 2002b), the ankylosaurs (Canudo et al., 2004), the theropods (RuizOmeñaca and Canudo, 2003; Ruiz-Omeñaca et al., 2005; Gómez-Fernández and Canudo, 2010) and the mammals (Badiola et al., 2008; 2009). The aim of this paper is to update the faunal list of the vertebrate and eggshell remains from the site of La Cantalera (Table 1) and to compare this fossil asociation with sites of the same age deposited in other palaeoenvironments in the same geographical area (Iberian Range in Teruel).

\section{Geographical and Geological Context}

The site of La Cantalera is located in the northeast of the Iberian Peninsula (Fig. 1), near the small village of Josa (Iberian Range, Teruel, Spain). The Iberian basin of northeast Spain is an intracratonic basin that developed during the Mesozoic extension (Salas et al., 2001). An Early Cretaceous stage of rifting resulted in the formation 
(1)

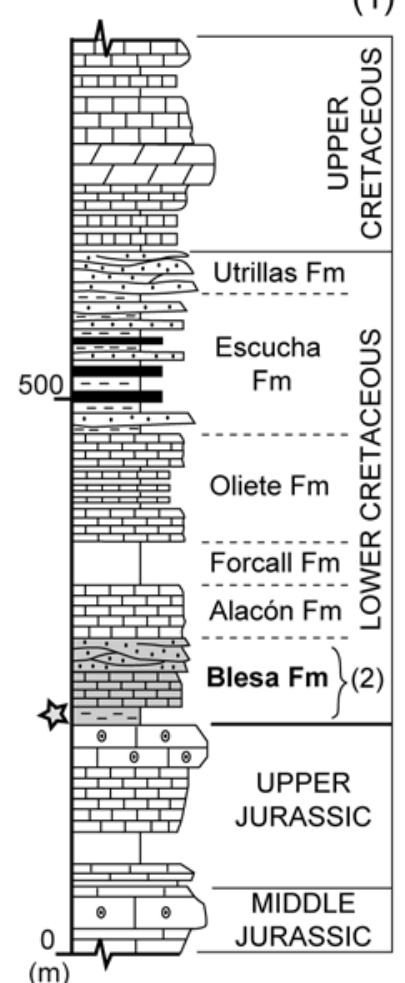

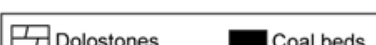

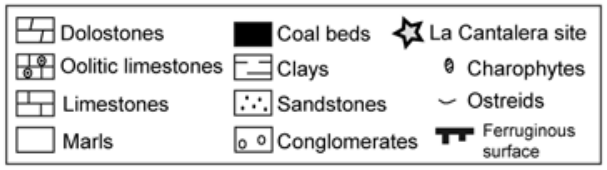
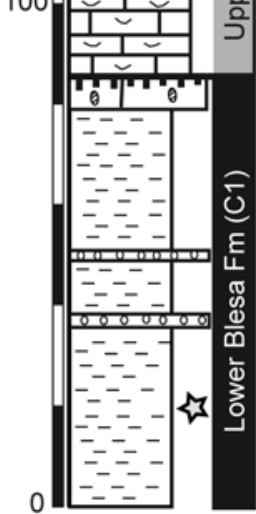

(2)
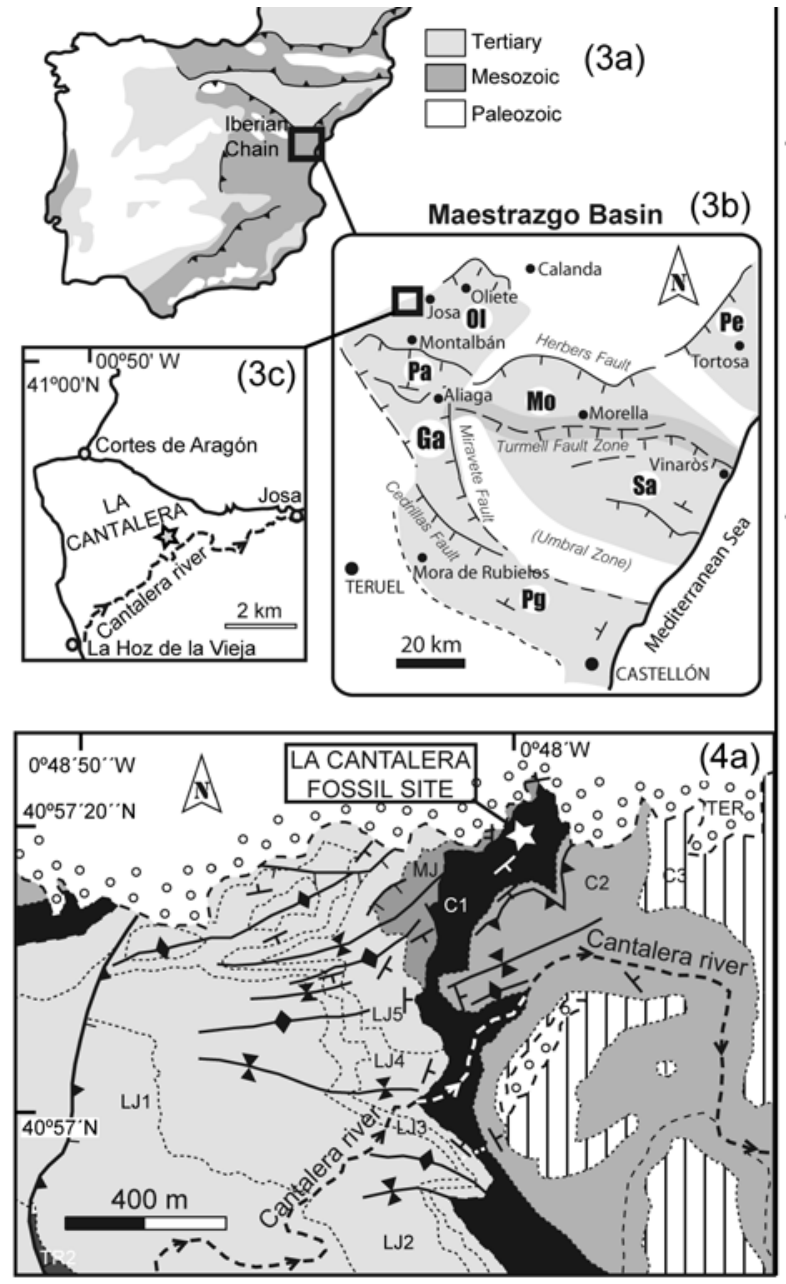

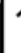

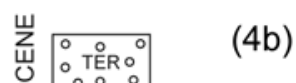

(4b) Conglomerates and clays

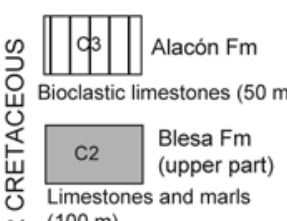
$(50-140 \mathrm{~m})$
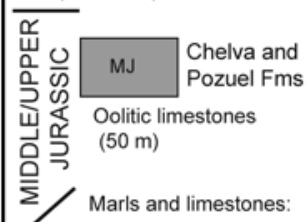

光 $\stackrel{\Upsilon}{\supset}(50 \mathrm{~m})$

Marls and limestones:

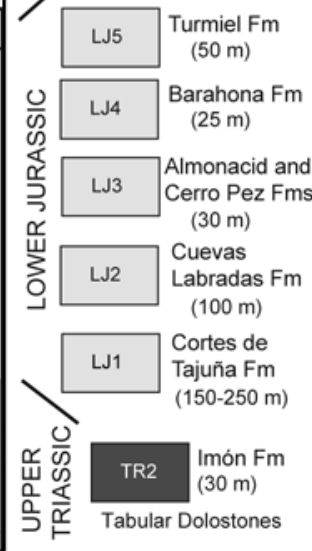

Fig. 1.- Geographical and geological location of La Cantalera site (late Hauterivian-early Barremian, Teruel, Spain). 1) Stratigraphical setting of the Blesa Formation, modified from Aurell et al. (2001). 2) Location of La Cantalera site within the Blesa Formation section. 3a) Simplified geologic map of the Iberian Peninsula. 3b) Palaeogeographic sub-basins (Ol: Oliete, Pa: Las Parras, Ga: Galve, Mo: Morella, Pe: Perelló, Sa: Salzedella, Pg: Peñagolosa) within the Maestrazgo basin and active faults during Early Cretaceous sedimentation, modified from Salas et al. (2001). 3c) Geographical location of La Cantalera site near the village of Josa, Teruel province, and 4) Geological mapping (a) in the area around $\mathrm{La}$ Cantalera site with the geological local units (b), modified from Aurell et al. (2004).

Fig. 1.- Situación Geografica y Geológica del yacimiento de La Cantalera (Hauteriviense superior-Barremiense inferior, Teruel, España). 1) Contexto estratigráfico de la Formación Blesa, modificado de Aurell et al. (2001). 2) Localización del yacimiento de La Cantalera dentro de la Formación Blesa. 3a) Mapa geológico simplificado de la Península Ibérica. 3b) Subcuencas paleogeográficas (Ol: Oliete, Pa: Las Parras, Ga: Galve, Mo: Morella, Pe: Perelló, Sa: Salzedella, Pg: Peñagolosa) dentro de la Cuenca del Maestrazgo y fallas activas durante la sedimentación durante el Cretácico Inferior, modificado de Salas et al. (2001). 3c) Localización geográfica del yacimiento de La Cantalera, próximo a Josa, provincia de Teruel, y 4) Cartografía geológica (a) del entorno del yacimiento de La Cantalera con las unidades geológicas locales (b), modificados de Aurell et al. (2004).

of several subsident areas across the Iberian basin, including the Oliete subbasin, which is where the site of $\mathrm{La}$ Cantalera is found (Fig. 1.3). The Oliete subbasin is located within the large cretacic Maestrazgo basin (Soria de Miguel, 1997; Salas et al., 2001). This site is an outcrop of Early Cretaceous clays ("Wealden facies"), specifically clays from the Blesa Formation. This lithostratigraphic unit has a complex evolution, including a lower part with alluvial to lacustrine sedimentation, followed by an upper part with two episodes of coastal lagoonal influence. The lower and the upper Blesa Formation are separated by a prominent ferruginous and encrusted surface developed over lacustrine carbonates (Fig. 1.2).

The fossiliferous level outcrops over a broad area due to the fact that its dip coincides with the slope. In lithological terms, La Cantalera comprises grey clays deposited in the lowest part of the lower Blesa Formation. Laterally these grey clays present a great abundance of rounded edges of Jurassic limestone with invertebrate marine fossils (ammonites, brachiopods, crinoids...), which is proof 
of the contribution of Jurassic clasts from the nearby Jurassic reliefs when the site was being formed. Detailed mapping and facies analysis of the lower Blesa Formation around the site of La Cantalera (Aurell et al., 2004) shows the existence of a set of N-S to NE-SW trending normal faults (Fig. 1.4), controlling the existence of a small, isolated basin surrounded by a relief formed by the marly-limestone, uplifted Jurassic units.

Among the microfossils ostracods and charophytes are very abundant, forming the greater part of the residue of the screen-washing over $0.150 \mathrm{~mm}$. Also frequent are plant fragments, microvertebrate remains (especially teeth) and continental gastropods. The charophyte association, which includes oogonia attributed to Atopochara trivolvis triquetra (Grambast, 1968), dates the locality of La Cantalera as late Hauterivian-early Barremian in age (Triquetra subzone), and, by approximation, the rest of the lower part of the Blesa Formation (Soria et al., 1995; Canudo et al., 2002a; Aurell et al., 2004). This charophyte association is similar in biostratigraphical terms to the one located in the El Castellar Formation of the Galve subbasin, which belongs to the southwestern part of the large Maestrazgo basin (Soria de Miguel, 1997; Salas et al., 2001). La Cantalera has been interpreted as deposited in a marshy environment with periodic droughts resulting in a non-permanent body of water and a marshy vegetated area (Aurell et al., 2004).

\section{Vertebrate Fossil Record}

The fossil vertebrate association of La Cantalera site described in this paper is housed in the Museo Paleontológico de la Universidad de Zaragoza (MPZ).

\subsection{Osteichthyans}

The presence of pisciform remains at the site of $\mathrm{La}$ Cantalera is merely token, since only one very smallsized vertebra has been recovered that can be attributed to Osteichthyes on the basis of its morphology. Given that most non-teleost actinopterygians have poorly ossified vertebral centra, this small vertebra can be identified as Teleostei indet.

\subsection{Lissamphibians}

Some small bone fragments from the site of La Cantalera are referred to the lissamphibians, documenting the presence of at least two taxa: a salamander-like albanerpetontid and a discoglossid frog (Table 1). The albanerpetontids are represented by two right humeri (Fig. 2) and four dentaries, while the discoglossid frog is represented by one right humerus and twenty fragments of tibiofibulae. Because of the fragmentation of the fossil material identification beyond the family level is difficult. Nevertheless the presence of an interdigitating symphysis (a hinge-like arrangement) between dentaries and of humeri with a straight and slender shaft, in line with the well-ossified and almost spherical condylar ball, permits a clear assignment to the family Albanerpetontidae.

Three albanerpetontid genera are currently recognized: Albanerpeton, Anoualerpeton, and Celtedens (McGowan, 2002; Gardner et al., 2003; Gardner and Böhme, 2008). During the Hauterivian and Barremian the family Albanerpetontidae is represented in Europe by the genera Celtedens and probably Albanerpeton (see Gardner and Böhme, 2008 for a review; Buscalioni et al., 2008). In the Iberian Peninsula albanerpetontid remains have been mentioned in the early Barremian of Galve in Teruel (Albanerpetontidae indet.; Estes and Sanchiz, 1982b), and in the Barremian of Las Hoyas (Celtedens ibericus; McGowan, 2002) and Uña (Celtedens megacephalus Costa 1864 and Albanerpeton? n. sp.; Wiechmann, 2000) and Buenache de la Sierra (cf. Albanerpeton sp.; Buscalioni et al., 2008) in Cuenca.

On the other hand, the frog humerus has a large well-ossified humeral ball (eminentia capitata) and a rather long ulnar epicondyle concordant with an attribution to the family Discoglossidae (Fig. 2). It is rather similar to the distal fragments from the Barremian of Galve described by Estes and Sanchiz (1982a) and attributed to the genus Eodiscoglossus, with an ulnar epicondyle that does not reach the posterior level of the eminentia capitata distally and a medial epicondyle that is very small. The fossa $\mathrm{cu}$ bitus ventralis is hidden by the sediment in our fossil, but seems to have been rather small, as in Eodiscoglossus. In the North American Paradiscoglossus americanus Estes and Sanchiz, 1982, the ulnar epicondyle reaches posteriorly to the distal level of the ball, and the fossa cubitus ventralis is well defined (Estes and Sanchiz, 1982b). No humeri of Wealdenbatrachus and Paralatonia have been described yet. Our fossil humerus probably also differs from the humeri of the pipoid Neusibatrachus wilferti Seiffert, 1972, from the late Berriasian - early Valanginian of El Montsec (Lleida province), the eminentia capitata of which remained incompletely ossified (Báez and Sanchiz, 2007), and from isolated humeri of the representatives of the family Palaeobatrachidae, which have two rather symmetrical epicondyles (= similarly developed) (Hossini, 1992).

Discoglossid frogs are rather common in the European Cretaceous fossil record and are represented by the gen- 


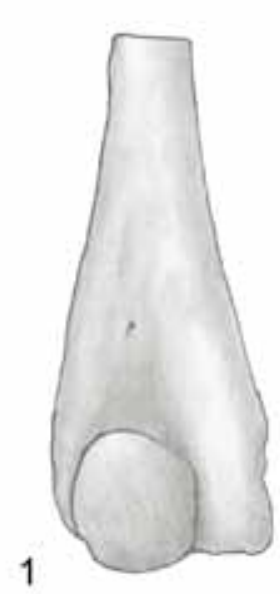

\section{$2 a$}

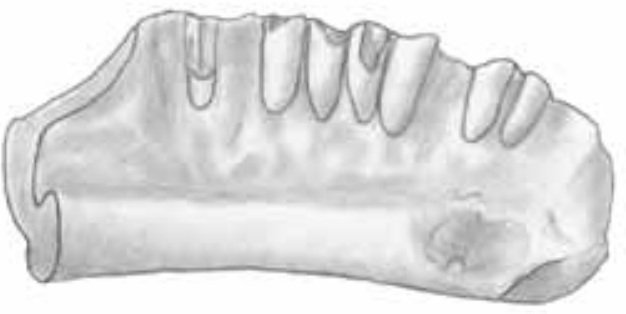

$2 b$

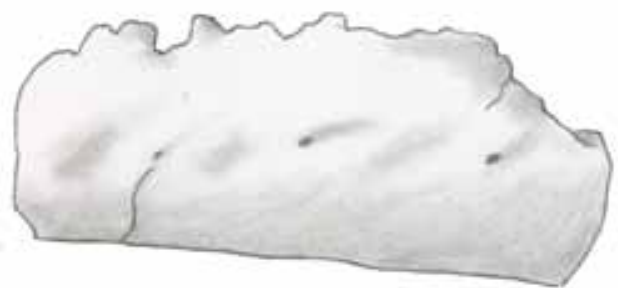

3
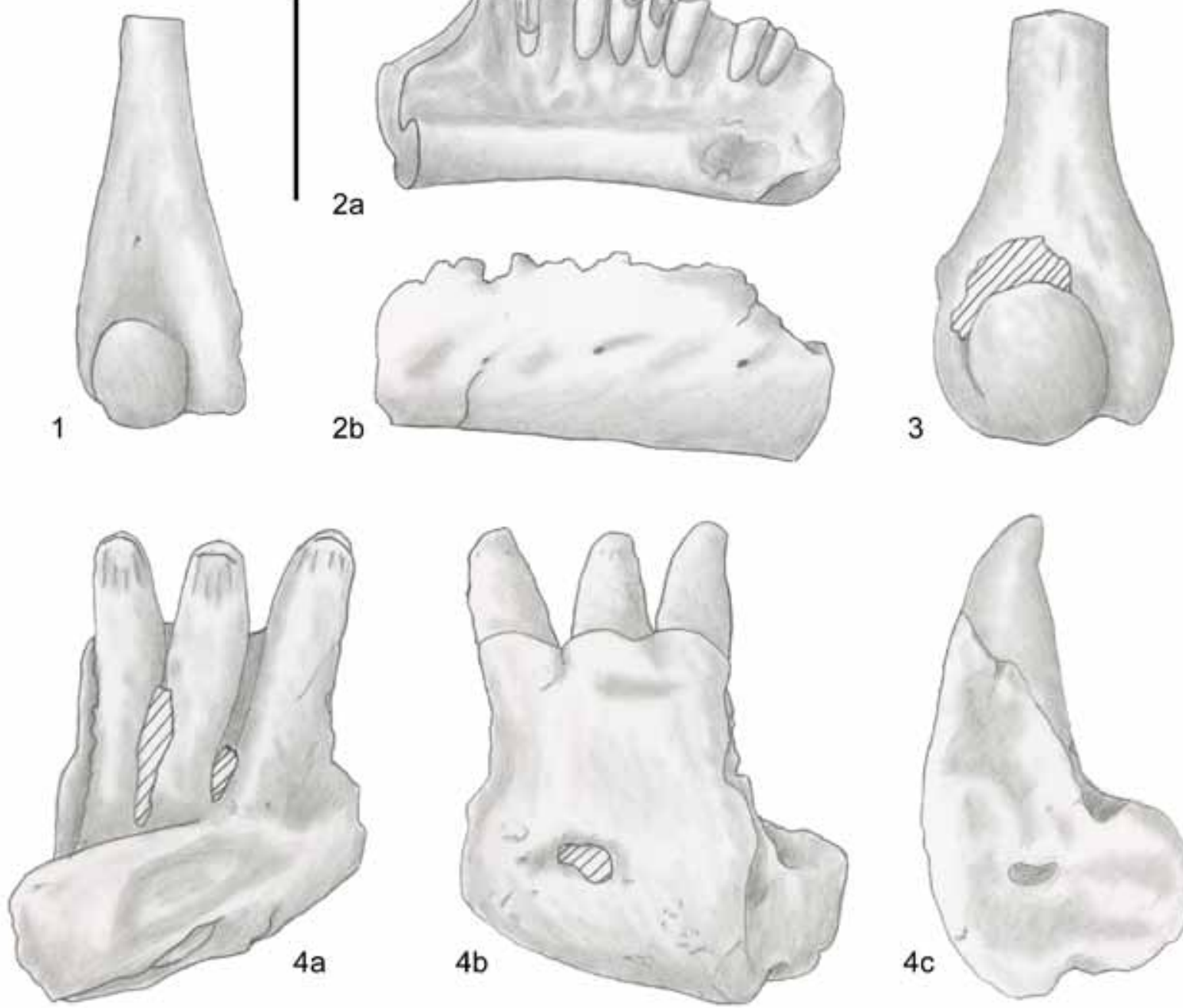

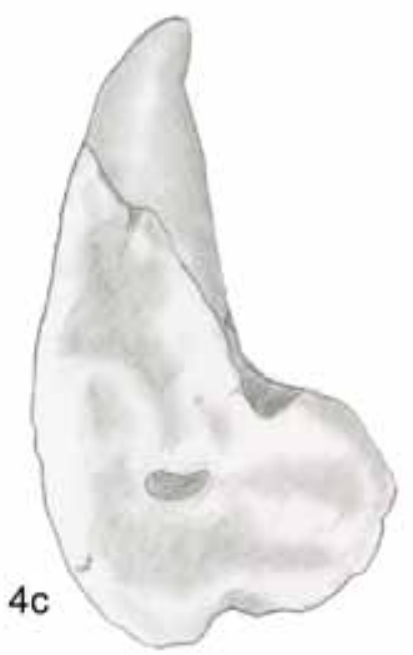

Fig. 2.- Lissamphibians and lacertilians fossil remains from La Cantalera site (late Hauterivian-early Barremian, Teruel, Spain). 1) Right humerus (CAN1-1626) of an indeterminate albanerpetontid in ventral view. 2) Left dentary (CAN1-1627) of an indeterminate albanerpetontid in lingual (a) and lateral (b) views. 3) Right humerus of indeterminate female discoglossid in ventral view. 4) Fragment of dentary (CAN1-1629) of indeterminate lizard (Paramacellodidae? indet.) in lingual (a), labial (b) and anterior or posterior (c) views. Scale bar is $1 \mathrm{~mm}$.

Fig. 2.- Restos fósiles de anfibios y lacértidos del yacimiento de La Cantalera (Hauteriviense superior-Barremiense inferior, Teruel, España). 1) Húmero derecho (CAN1-1626) en vista ventral de un albanerpetóntido indeterminado. 2) Dentario izquierdo (CAN11627) de un albanerpetóntido indeterminado (a) en vista lingual y (b) lateral. 3) Húmero derecho de discoglósido hembra en vista ventral. 4) Fragmento de dentario (CAN1-1629) de un largarto indeterminado (Paramacellodidae? indet.) en vista lingual (a), labial (b) y anterior o posterior (c). La escala es $1 \mathrm{~mm}$.

era Eodiscoglossus, Paradiscoglossus, Wealdenbatrachus, and Paralatonia (Sanchiz, 1998; Venczel and Csiki, 2003; Folie and Codrea, 2005). During the Hauterivian and Barremian in the Iberian Peninsula, Discoglossidae are represented by Eodiscoglossus cf. santonjae Villalta 1957 in the early Barremian of Galve in Teruel (Estes and Sanchiz, 1982b; Sanchiz, 1998), Eodiscoglossus sp. and Wealdenbatrachus cf. jucarense Fey 1988 in the Barremian of Las Hoyas in Cuenca (Sanz et al., 1988; Sanchiz, 1998), and Wealdenbatrachus jucarense in the Barremian of Uña in Cuenca (Fey, 1988; Sanchiz, 1977 and 1998). For the moment due to the low number of remains, that they are not diagnostical beyond family level and to their incompleteness no more precise attribution is possible.

\subsection{Chelonians}

Chelonian remains are very rare in La Cantalera. They are currently represented by small peripheral plates tentatively referred to Pleurosternidae. These display the 
external ornamentation pattern present on the plates of this family, already present in the Barremian of Cuenca Province (Pérez García, 2009).

\subsection{Squamate reptiles}

Squamate reptiles are represented in the site of La Cantalera by some poorly preserved remains: two fragments of dentaries, two indeterminate tooth-bearing fragments (Fig. 2) and one fragment of a vertebra. The tooth morphology of the best-preserved fragments is concordant with an indeterminate scincomorph, very probably a paramacellodid lizard (Paramacellodidae? indet. in Table 1). Richter (1994a, 1994b) has described several squamate taxa in the late Hauterivian - early Barremian of Galve (Teruel, Spain), including paramacellodids in the El Castellar and Camarillas Formations.

\subsection{Crocodylomorphs}

Isolated teeth from small-sized crocodylomorphs are found in great abundance by screen-washing sediments from La Cantalera. Small-sized vertebral centra and dermal plates have also been found, though these have not yet been studied. It is difficult to work out the systematics at the species level on the basis of crocodylomorph teeth from the Early Cretaceous of the Iberian Peninsula, at least while we lack more complete specimens with teeth in the jaws. In a morphometric study of different sites of the late Hauterivian and Barremian of Galve (Teruel) and Cuenca, Buscalioni and Sanz (1984) and Buscalioni et al. (2008) draw a distinction between three morphotypes which they relate with the neosuchians Goniopholis, Theriosuchus and Bernissartia, which are also found in La Cantalera (Ruiz-Omeñaca et al., 1997). A fourth morphotype with morphology similar to Lisboasaurus (Ortega, 2004) is also represented in La Cantalera. In addition to these four morphotypes, there are crocodylomorph teeth in La Cantalera that clearly do not belong to any of them. These include conical teeth without any crest ornamentation on the enamel and conical teeth with denticulate carinae. The scarcity of these morphotypes (1\%) makes it difficult to tell as yet whether they are distinct taxa or whether they might represent heterodonty in one of the four recognized morphotypes.

The most abundant crocodylomorph teeth $(47 \%)$ are those assigned to Goniopholididae indet. These teeth are small-to-medium in size, generally less than $1 \mathrm{~cm}$, which distinguishes them from larger forms such as Goniopholis cf. crassidens Owen 1841 of Galve (Buscalioni and Sanz, 1987) and brings them closer to juvenile individu- als or small dwarf taxa of this family (Buscalioni et al., 2008). They display a conical morphology, with a high crown, and are slightly compressed labiolingually and somewhat curved towards the lingual side. Many of the specimens present mesial and distal carinae without denticles. They exhibit enamel ornamentation formed by a variable number of labial and lingual crests. Teeth with this morphology have traditionally been assigned to Goniopholididae or to the genus Goniopholis (Buscalioni and Sanz, 1984; Buscalioni et al., 2008). Until we have recovered more complete material, it is considered preferable to leave the assignation at the family level. The atoposaurids are represented by two morphotypes that have been regarded as a variation of the same taxon. They make up $7 \%$ of the crocodyliform teeth of La Cantalera. They are small teeth that do not generally reach $3.0 \mathrm{~mm}$ in size. The most characteristic morphotype comprises teeth with a low crown (which are wider mesiodistally than high) and a distinctive leaf-shape. The labial side is convex, and the lingual is flat or slightly convex. They present mesial and distal carinae that twist lingually towards the base of the tooth. The ornamentation is very characteristic, formed by fine striae that are convergent in the central area of the tooth and divergent towards the mesial and distal sides. The second morphotype is lanceolate (higher than wide mesiodistally), and the carinae do not show any lingual twist. These teeth exhibit the distinctive characters of the family of Atoposauridae in the broad sense: they are leaf-shaped or lance-shaped teeth, with lateromedial compression of the crown, ornamentation consisting of fine longitudinal and oblique crests, and significant heterodonty (Wellnhofer, 1971). The first morphology in particular has been associated with Theriosuchus in the Barremian of the Iberian Peninsula (Buscalioni and Sanz, 1984; Ruiz-Omeñaca et al., 2004; Buscalioni et al., 2008). Bearing in mind that only tooth remains have been found, it has been considered preferable to leave open the nomenclature of the atoposaurid from La Cantalera (cf. Theriosuchus sp.).

A third type presents morphologies that are clearly distinguishable from the other crocodylomorphs due to its "molariform" appearance (29\%). The most characteristic ones have very low crowns and a blunt apex. The section is sub-rounded or sub-square. They exhibit ornamentation in the form of fine crests that converge towards the apex. The neck of the root shows a marked constriction. These are possibly the most posterior teeth in the dental series. There are teeth with similar morphologies that are distinguished by the fact that they are almost as high as wide mesiodistally and have a characteristic figure-ofeight section. The morphology that seems to be the most 
anterior in the dental series is presented by certain teeth that are slightly higher than wide mesiodistally and oval in section. Teeth with this morphology have been assigned to Bernissartia, Unasuchus (close to Bernissartia) and to Bernissartiidae in the Barremian of the Iberian Peninsula (Buscalioni and Sanz, 1990; Brinkman, 1992; Buscalioni et al., 2008). Bearing in mind the great variability among these "molariform" teeth and the fact that they might belong to more than one taxon, it has been considered preferable to refer them to Bernissartiidae indet.

The fourth morphotype has a morphology that can be distinguished from the previous three. It is represented by $16 \%$ of the crocodyliform teeth from La Cantalera. These are very small teeth with an overall triangular outline. They are very much flattened labiolingually. The labial side is convex, and the lingual almost flat. They display fine mesial and distal carinae. They show ornamentation consisting of crests that converge towards the apex, both on the labial and the lingual side. This morphotype bears a great resemblance to the teeth of Lisboasaurus and the LH-Crocodyliform, a member of Mesoeucrocodylia informally described in the late Barremian site of Las Hoyas in Cuenca (Ortega, 2004). The latter author proposes that the LH-Crocodyliform and Gobiosuchus are grouped at the same node, which is of great palaeogeographical and systematic interest. It would be the only crocodyliform of the Iberian Early Cretaceous that is not a neosuchian, and moreover it would be related with an Asian form (Gobiosuchus), as is the case with other vertebrates from La Cantalera.

\subsection{Pterosaurians}

There are isolated teeth of at least two different pterosaurs. The first morphotype comprises small teeth that are markedly flattened lateromedially, triangular in shape, somewhat higher than wide, with a slight distal displacement of the apex, and a basal constriction. Morphologically similar teeth from the late Barremian sites of Las Hoyas and Vallipón (Ruiz-Omeñaca et al., 1998) have been referred to the family Istiodactylidae (Vullo et al., 2009). We tentatively refer the first morphotype from La Cantalera to this family, but in open nomenclature. The second morphotype is represented by teeth of a larger size and with a circular section, much higher than wide, and with a slight lingual curvature of the apex. This type of morphology has been associated with Ornithocheiridae (Ruiz-Omeñaca et al., 1998; Wellnhofer and Buffetaut, 1999; Vullo et al., 2009), and so they are here tentatively assigned to this family.

\subsection{Dinosaurs}

The dinosaur record displays exceptional richness in ornithopod and theropod teeth. The biodiversity preserved in La Cantalera has been ascertained on the basis of these teeth. Although the site also includes isolated postcranial remains, these are for the most part under study, and so have not been included in this paper.

\section{Ornithopoda}

Ornithopods are the most abundant dinosaur remains within the La Cantalera fossil assemblage (RuizOmeñaca et al., 1997; Ruiz-Omeñaca, 2006). Extremely abundant isolated teeth and few postcranial remains are represented. The postcranial remains are for the most part fragmentary and disarticulated elements such as isolated vertebral centra, except for a partially articulated caudal series which belongs to an undetermined ornithopod dinosaur. This semi-articulated caudal series comprises several vertebrae with amphicoelous centra and a hexagonal cross-section typical of Ornithopoda (e.g. Galton, 1974: fig. 32; Norman, 1986: fig. 41; Norman et al., 2004). However, the dental record is more diagnostic and allows several morphotypes to be distinguished (Fig. 3). These can be assigned to different taxa: Iguanodontoidea indet., "Hypsilophodontidae" indet., Hadrosauroidea? indet., Rhabdodontidae? indet.

The ornithopod teeth are mostly terminally resorbed. Around 400 specimens have been collected. Most of them are shed teeth, and only a few are functional crowns or replacement teeth with the enamel preserved. The exceptional accumulation of shed teeth supports the hypothesis that the area of La Cantalera was a place where phytophagous dinosaurs lost resorbed teeth from their dental rows during feeding (Ruiz-Omeñaca et al., 1997), as explained in the introduction. In the terminal replacement stages more teeth became undefined, completely losing the original morphology. As a result a third of the collection of ornithopod teeth cannot be assigned to any dental morphotype. Among the identifiable teeth, $80 \%$ have been assigned to Iguanodontoidea (216 specimens). Less frequent are the "Hypsilophodontid" morphotypes (32 specimens). Only a few teeth can be included within other ornithopod morphotypes that resemble hadrosauroid crowns (16 specimens), and one fragment of a crown shows features similar to Rhabdodontidae.

The teeth included in Iguanodontoidea (Fig. 3.1, 3.2) show a great variety of size, representing adult and juvenile individuals. They have high crowns, labiolingually compressed with denticles on the margin. One side is enamelled and ridged: the labial side in maxillary 
crowns, and the lingual side in dentary crowns, in accordance with Norman (2004: 424). The other side is smooth and without enamel. The wear facets are expanded mesiodistally. They are inclined toward the smooth side and slightly mesially in maxillary teeth, and distally in dentary teeth. The wear facets tend to increase in width, especially in dentary crowns that are extremely worn. The maxillary crowns (Fig. 3.1) show a very prominent vertical ridge displaced distally and several subsidiary ridges, usually mesially offset (Ruiz-Omeñaca et al., 1997: figs. $5,6)$. The subsidiary ridges are variable in number and can even be located superimposed over the primary ridge. The dentary crowns (Fig. 3.2) show numerous weak vertical ridges that sometimes converge apically.

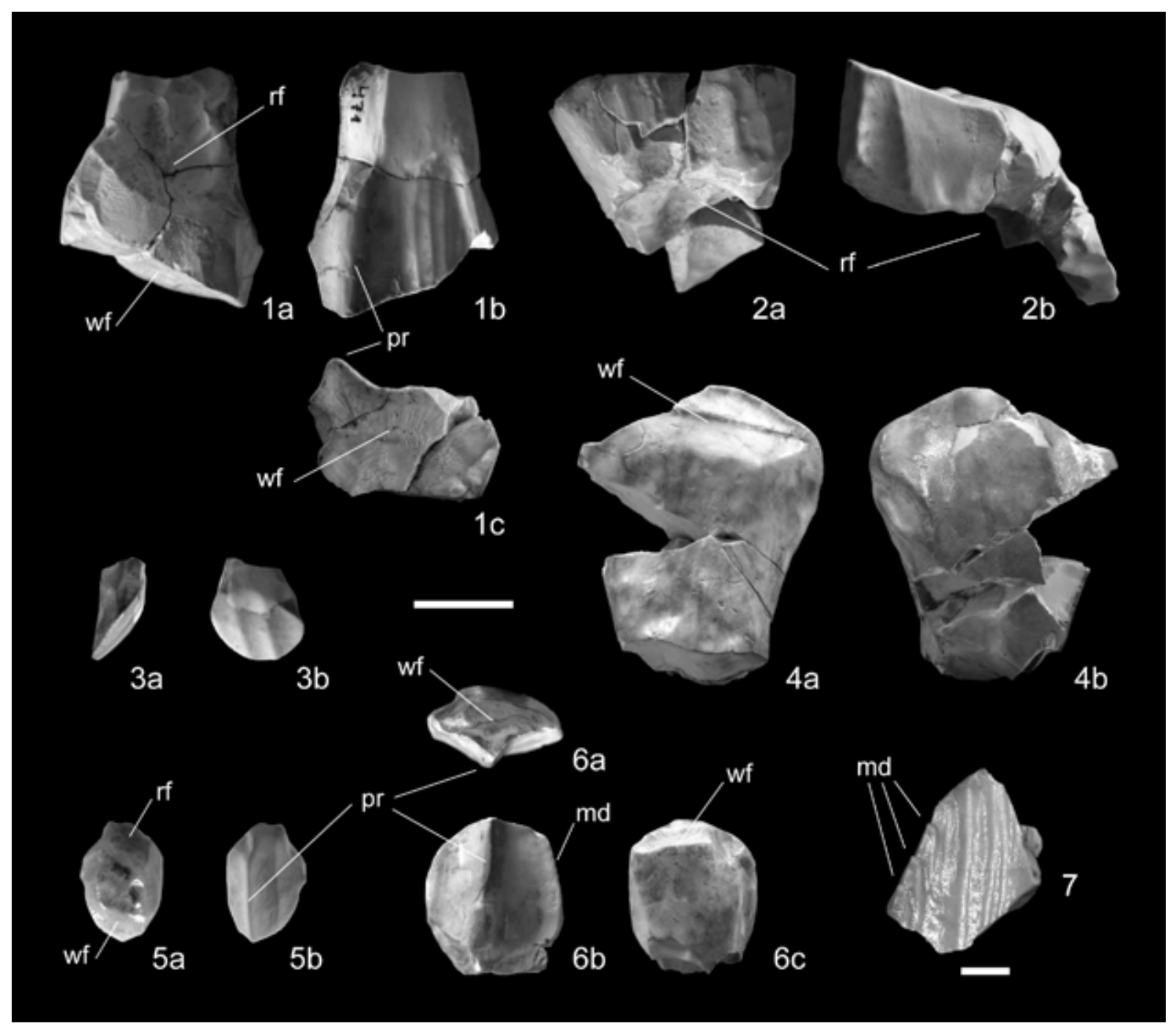

Fig. 3.- Ornithopod teeth from La Cantalera site (late Hauterivian-early Barremian, Teruel, Spain). 1-2) Iguanodontoidea indet: right maxillary tooth (MPZ 97/471) in lingual (1a), labial (1b) and occlusal (1c) views; left dentary tooth (MPZ 97/472) in lingual (2a) and mesial (2b) views. 3-4) "Hypsilophodontidae" indet: left maxillary tooth (CAN1-699) in mesial (3a) and labial (3b) views; left dentary tooth (CAN1-904) in labial (4a) and lingual (4b) views. 5-6) Hadrosauroidea? indet: right maxillary tooth (CAN1-925) in lingual (5a) and labial (5b) views; left dentary tooth (MPZ 97/477) in occlusal (6a), lingual (6b) and labial (6c) views. 7) Rhabdodontidae? indet: undetermined tooth (CAN1-1616). Scale bars are $1 \mathrm{~cm}$ (from subfigure1 to 6 ) and $1 \mathrm{~mm}$ (subfigure 7). Abbreviations: prominent primary ridge (pr), wear facet (wf), reabsorption facet (rf), marginal denticles (md).

Fig. 3.- Dientes de ornitópodos del yacimiento de La Cantalera (Hauteriviense superior - Barremiense inferior, Teruel, España). 1-2) Iguanodontoidea indet: diente maxilar derecho (MPZ 97/471) en vista lingual (1a), labial (1b) y oclusal (1c); diente mandibular izquierdo (MPZ 97/472) en vista lingual (2a) y mesial (2b). 3-4) "Hypsilophodontidae" indet: diente maxilar izquierdo (CAN1-699) en vista mesial (3a) y labial (3b); diente mandibular izquierdo (CAN1-904) en vista labial (4a) y lingual (4b). 5-6) ¿Hadrosauroidea? indet: diente maxilar derecho (CAN1-925) en vista lingual (5a) y labial (5b); diente mandibular izquierdo (MPZ 97/477) en vista oclusal (6a), lingual (6b) y labial (6c). 7) ¿Rhabdodontidae? indet: diente indeterminado (CAN1-1616). Las escalas gráficas valen $1 \mathrm{~cm}$ (desde la subfigura1 a la 6) y $1 \mathrm{~mm}$ (subfigura 7). Abreviaciones: cresta primaria prominente (pr), faceta de desgaste (wf), faceta de reabsorcion (rf), dentículos marginales (md). 


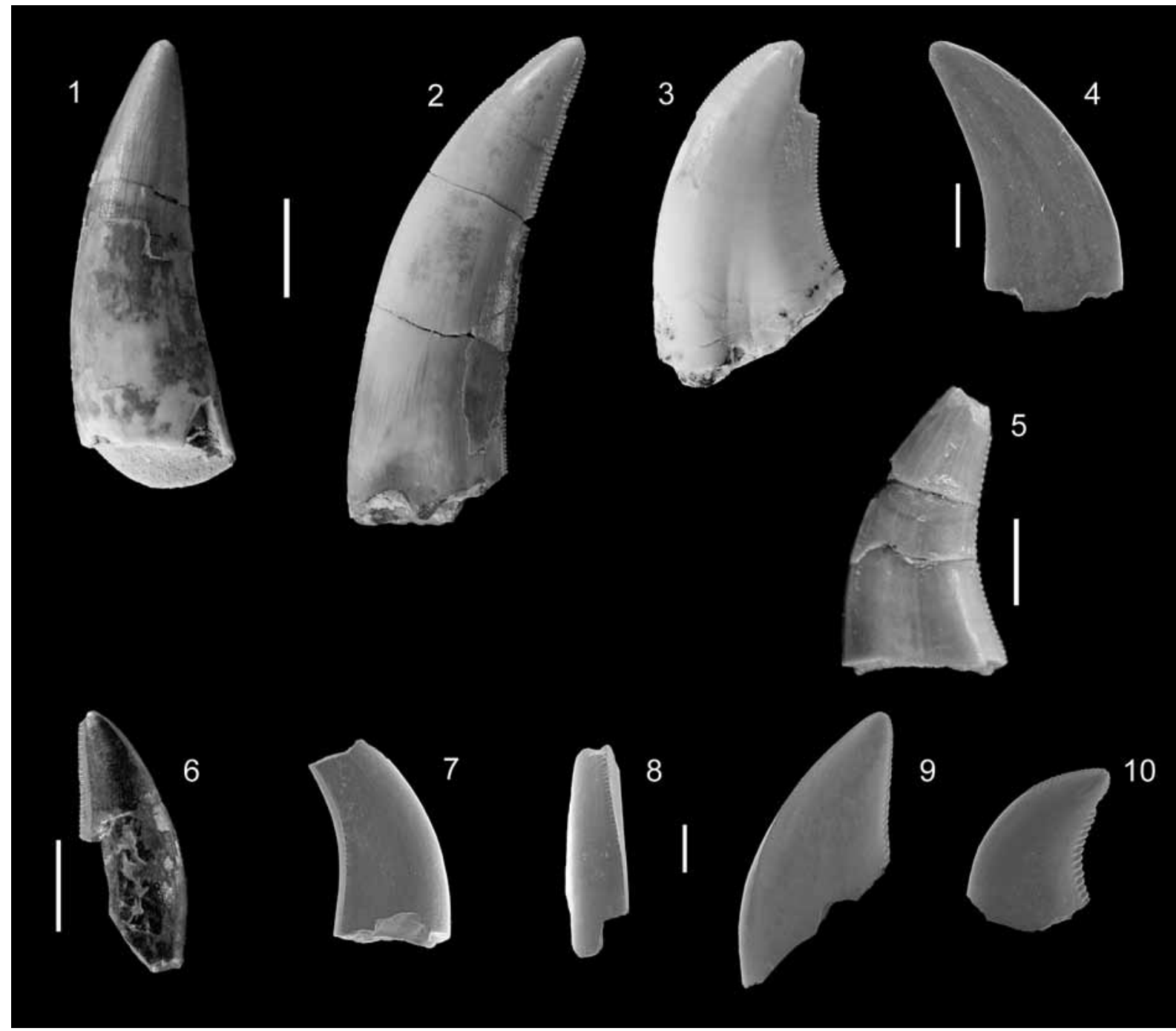

Fig. 4.- Theropod teeth from La Cantalera site (late Hauterivian-early Barremian, Teruel, Spain). 1) Baryonychinae indet. (CAN1-957). 2) Carcharodontosauridae? indet. (CAN1-963). 3) Dromaeosaurinae indet. 1 (CAN1-979). 4) aff. Paronychodon sp. (CAN1-1035). 5) Maniraptora indet. 2 (CAN1-1043). 6) Maniraptora indet. 3 (MPZ2003/232). 7) Maniraptora indet. 1 (CAN1-1031). 8) Dromaeosaurinae indet. 2. (CAN1-1001). 9) Dromaeosaurinae indet. 3 (CAN1-1058). 10) Velociraptorinae indet. (CAN1-1029). The scale bar is $5 \mathrm{~mm}$ in 1-3. In 4 is $0,5 \mathrm{~mm}$. In 5 is $2 \mathrm{~mm}$. In 6 is $5 \mathrm{~mm}$. In $6-10$ is $1 \mathrm{~mm}$.

Fig. 4.- Dientes de terópodos del yacimiento de La Cantalera (Hauteriviense superior-Barremiense inferior). 1) Baryonychinae indet. (CAN1-957). 2) Carcharodontosauridae? indet. (CAN1-963). 3) Dromaeosaurinae indet. 1 (CAN1-979). 4) aff. Paronychodon sp. (CAN1-1035). 5) Maniraptora indet. 2 (CAN1-1043). 6) Maniraptora indet. 3 (MPZ2003/232). 7) Maniraptora indet. 1 (CAN1-1031). 8) Dromaeosaurinae indet. 2. (CAN1-1001). 9) Dromaeosaurinae indet. 3 (CAN1-1058). 10) Velociraptorinae indet. (CAN1-1029). La escala es $5 \mathrm{~mm}$ en 1-3. En 4 es 0,5mm. En 5 es $2 \mathrm{~mm}$. En 6 es $5 \mathrm{~mm}$. En 7-10 es $1 \mathrm{~mm}$.

The teeth included in "Hypsilophodontidae" (Fig. $3.3,3.4)$ are generally small and medium-sized teeth, but some large teeth (Fig. 3.4) have been found (RuizOmeñaca and Canudo, 2001: fig. 12). The crowns are labiolingually compressed with denticles on the margin, but these crowns are more asymmetrical and expanded mesiodistally than in the iguanodontoid morphotype. The wear facets are more expanded mesiodistally and inclined, likewise slightly mesially in maxillary teeth and distally in dentary teeth (Galton, 1974: figs. 14-16). However the ridge pattern on the ornamented side is notably different. The maxillary teeth (Fig. 3.3) have a labial side characterized by several weak vertical ridges, whereas the dentary teeth (Fig. 3.4) have a lingual side characterized by weak vertical ridges, as well as one apical ridge that is more prominent (Galton, 1974; Ruiz-Omeñaca et al., 1997).

The teeth included in Hadrosauroidea? (Fig. 3.5, 3.6) present high crowns that are labiolingually compressed. The wear facets are very much inclined toward the smooth side and have a diffuse outline. On the ornamented side, these teeth exhibit just one very prominent verti- 
cal ridge located in a subcentral position or slightly distally with respect to the midline, as in figure 3.6a,b. This morphology probably corresponds to mandibular teeth (Ruiz-Omeñaca et al., 1997: fig. 6.3), whereas there are some crowns with a very prominent ridge displaced distally and only one subsidiary ridge mesially (Fig. 3.5b), which could represent maxillary teeth belonging to the same taxon. This pattern of single developed ridges and the height of the crowns are synapomorphies of hadrosauroids (Norman, 2002; Godefroit et al., 2005; Vullo et al., 2007), which indicates the presence of a derived member of Iguanodontoidea at La Cantalera.

A fragment of one crown with denticles on the margin and only one side enamelled is included in Rhabdodontidae? (Fig. 3.7). The enamelled side exhibits weak parallel vertical ridges, finishing in terminal denticles on the apical margin. This morphotype represents an ornithopod taxon from La Cantalera that is different from the others, and resembles the dental morphology present in rhabdodontids (Weishampel et al., 2003; Osi, 2004; Torcida Fernández-Baldor et al., 2005).

\section{Thyreophora}

The thyreophorans are represented by two isolated teeth, dermal plates and one caudal vertebra. The fragments of the dermal skeleton are abundant and easy to identify on account of their characteristic ornamentation. The thyreophoran teeth from La Cantalera display the typical leaf shape, with large denticles on the mesial and distal margins. Their main diagnostic character is the absent cingulum and their smooth enamel (Canudo et al., 2004). The absence of a cingulum is a derived character shown by certain ankylosaurids, making it possible to associate the thyreophorans from La Cantalera with Gastonia, a polacanthine (or polacanthid) from the Barremian of the USA (Kirkland, 1998). The dermal plates display morphology similar to that described for the remains of Polacanthus from the Iberian Peninsula (Pereda-Suberbiola et al., 2007). The ankylosaurian from La Cantalera confirms the presence of a taxon close to the English genus Polacanthus, which could be Ankylosauridae, Polacanthinae or Polacanthidae (according to the classification used), but in any case different from Nodosauridae on account of the absent cingulum in the teeth (Canudo et al., 2004).

\section{Sauropoda}

Sauropod remains are very scarce in La Cantalera. Two isolated teeth are known, as are fragments of a third (Canudo et al., 2002b; Ruiz-Omeñaca et al., 2003), a very damaged cervical vertebra and fragments of cancellate tissue from vertebrae. The teeth are especially interest- ing, presenting morphology similar to Euhelopus of the Early Cretaceous of China. The teeth are spatulate, with V-shaped wear facets and two small cusps situated at the base of the dental crown ("cingular cusps"). Taking into account that the material is fragmentary, the sauropod from La Cantalera has been classified as Euhelopodidae indet. (Canudo et al., 2002b). Euhelopus is a sauropod genus whose systematic position has varied considerably depending on the author, ranging from a non-neosauropod eusauropod to Somphospondyli (Wilson and Upchurch, 2009). This is of particular importance given that the first case would entail an endemic Asiatic form, whereas in the second case it would be a representative of a clade with a broad record in Laurasia. The recent revision of the genus has made it possible to place it in its correct chronostratigraphic position (Barremian-Aptian) and as a member of Somphospondyli (Wilson and Upchurch, 2009).

\section{Theropoda}

Small and medium-sized theropod teeth are abundant in La Cantalera (Fig. 4). As yet, no postcranial remains have been found that could be attributed to these carnivorous dinosaurs. Partial studies of some of the groups have been carried out, including work on a large maniraptoran (Ruiz-Omeñaca and Canudo, 2003) and on the teeth of baryonychine spinosaurids (Ruiz-Omeñaca et al., 2005). Recently a revision of all the morphotypes of theropod teeth has been carried out (Gasca et al., 2009; GómezFernández and Canudo, 2010). The taxa identified to date are included in basal tetanurans such as baryonychines and possible carcharodontosaurids, as well as coelurosaurians such as maniraptorans, dromaeosaurines, velociraptorines and "paronychodontids."

The baryonychine spinosaurids are represented by medium-sized teeth with little lateromedial compression (Fig. 4.1), rugose enamel and carinae with small denticles (Ruiz-Omeñaca et al., 2005; Gómez-Fernandez and Canudo, 2010). Teeth with these characters are very abundant in the Early Cretaceous of the Iberian Peninsula. They display great morphological variability, which indicates the presence of a number of different taxa, some of them clearly related with English forms such as $\mathrm{Ba}$ ryonyx (Martill and Hutt, 1996) and also with taxa from the north of Africa such as Suchomimus (Canudo et al., 2008a). The baryonychines from La Cantalera show significant variation in their lateromedial flattening and the number and development of their longitudinal crests, but for the moment this is regarded as variability within the same taxon.

There is a second basal tetanuran represented at $\mathrm{La}$ Cantalera. The remains in question are medium-sized, 
rather plesiomorphic teeth displaying slight enamel wrinkles, a feature that has been used as a diagnostic character of the carcharodontosaurid allosauroids (see references in Salgado et al., 2009). Brusatte et al. (2007) have called this character into question as an autapomorphy for the carcharodontosaurids, considering it instead to be a synapomorphy of a broader group that would incorporate various basal tetanurans including the carcharodontosaurids. Moreover, this character may appear in other groups distinct from the basal tetanurans, such as the carnotaurines of the Late Cretaceous of Argentina (Canale et al., 2008). However, the carnotaurines are a group of abelisaurs exclusively from the Late Cretaceous of South America and unrelated to the Iberian theropods of the Late Cretaceous. The teeth from La Cantalera further display bilobate denticles, a character cited exclusively in a carcharodontosaurid from the Early Cretaceous of South America (Novas et al., 2005). Indeed, the absence of mesial denticles in the basal half of the crown, together with the slight enamel wrinkles and the bilobate denticles, is a combination of characters only described in Carcharodontosauridae, for which reason the teeth from La Cantalera have been assigned to this family (Gómez-Fernández and Canudo, 2010). The presence of carcharodontosaurids at La Cantalera constitutes the first occurrence of this group in the Hauterivian-Barremian transition and demonstrates the presence of these carnosaurs in the Early Cretaceous of the Iberian Peninsula. This is consistent with the current context, given that in the most recent phylogenetic proposals Neovenator of the Barremian of England has been considered a carcharodontosaurid (Brusatte and Sereno, 2008). Recently Benson et al. (2010) have proposed a somewhat different scenario with their definition of the clade Carcharodontosauria. They distinguish between the families Carcharodontosauridae and Neovenatoridae (including Neovenator) within this clade. If we take this proposal into account, the teeth from La Cantalera would have to be considered carcharodontosaurian.

The rest of the theropod teeth from La Cantalera present a combination of characters that are derived for the tetanurans, such as marked lateromedial flattening, the absence of either or both of the denticulate carinae, and a posterior side that is markedly concave. Gómez-Fernández and Canudo (2010) have given a detailed description of these teeth, making it possible to differentiate eight distinct taxa (Maniraptora indet. 1, 2 and 3; Dromaeosaurinae indet. 1, 2 and 3; Velociraptorinae indet. and aff. Paronychodon sp.). These differ, among other characters, in the development of the carinae, the form and development of the denticles, the presence of longitudinal grooves, size etc. (Figs. 4.3-4.10). This diversity of small theropods in the Early Cretaceous of the Iberian Peninsula has come to light at other sites where screen-washing of sediments has been carried out (Rauhut, 2002), although at present the absence of postcranial remains makes it difficult to distinguish them any more precisely. In addition to these morphotypes clearly identifiable as theropods, there are tiny teeth with marked posterior curvature, without carinae, and with a bulbous base. These could belong to small birds (Avialae? indet. in Table 1).

\subsection{Mammals}

Mammals are represented by isolated multituberculate teeth assigned to three or four taxa (Badiola et al., 2008): one P4/5 and two M1 of the pinheirodontid taxon Cantalera abadi; two P5 from the eobaatarid Eobaatar sp.; one P1/3 and a p4 fragment of another taxon described as Plagiaulacidae or Eobaataridae gen. et sp. indet.; and two incisors (I2 and ?ix) of another taxon described as "Plagiaulacida indet." (Fig. 5). These fossils have increased the resolution of European Early Cretaceous multituberculate mammalian biodiversity, biostratigraphy and palaeobiogeography: (1) The discovery of a new late Hauterivian-early Barremian pinheirodontid taxon demonstrates greater biodiversity and a wider biostratigraphic distribution for these multituberculates than was previously known. (2) The oldest representative of Eobaatar is described in Western Europe. (3) The taxon described as Plagiaulacidae or Eobaataridae gen. et sp. indet. has also been identified in another Early Cretaceous (early Barremian) bed in the Iberian Range, in Galve (Teruel). All these specimens from the La Cantalera and Galve sites probably belong to a new taxon of the Plagiaulacidae family; if this assignment is correct, it will be the first record of this family in the Iberian Peninsula.

The late Hauterivian-early Barremian multituberculate fossil assemblage of the La Cantalera site comprises some taxa (Pinheirodontidae and probably Plagiaulacidae) that are currently recorded in Western Europe (Spain, Portugal, Britain and France), and others (Eobaataridae) that have also been described in Asia. Consistent with the Iberian Barremian records of sauropod and ornithopod dinosaurs and gobiconodontid mammals (Canudo et al., 2002b; Canudo, 2006; Cuenca-Bescós and Canudo, 2003), the presence of Eobaatar in Iberia with representatives from the late Hauterivian to late Barremian (Badiola et al., 2009), as well as in the Barremian of Britain (Sweetman, 2009) and in the Aptian or Albian of Asia (Kielan-Jaworowska et al., 1987), indicates that geographical connections between these Laurasian areas could have existed either sporadically or constantly for most of the Early Cretaceous. 


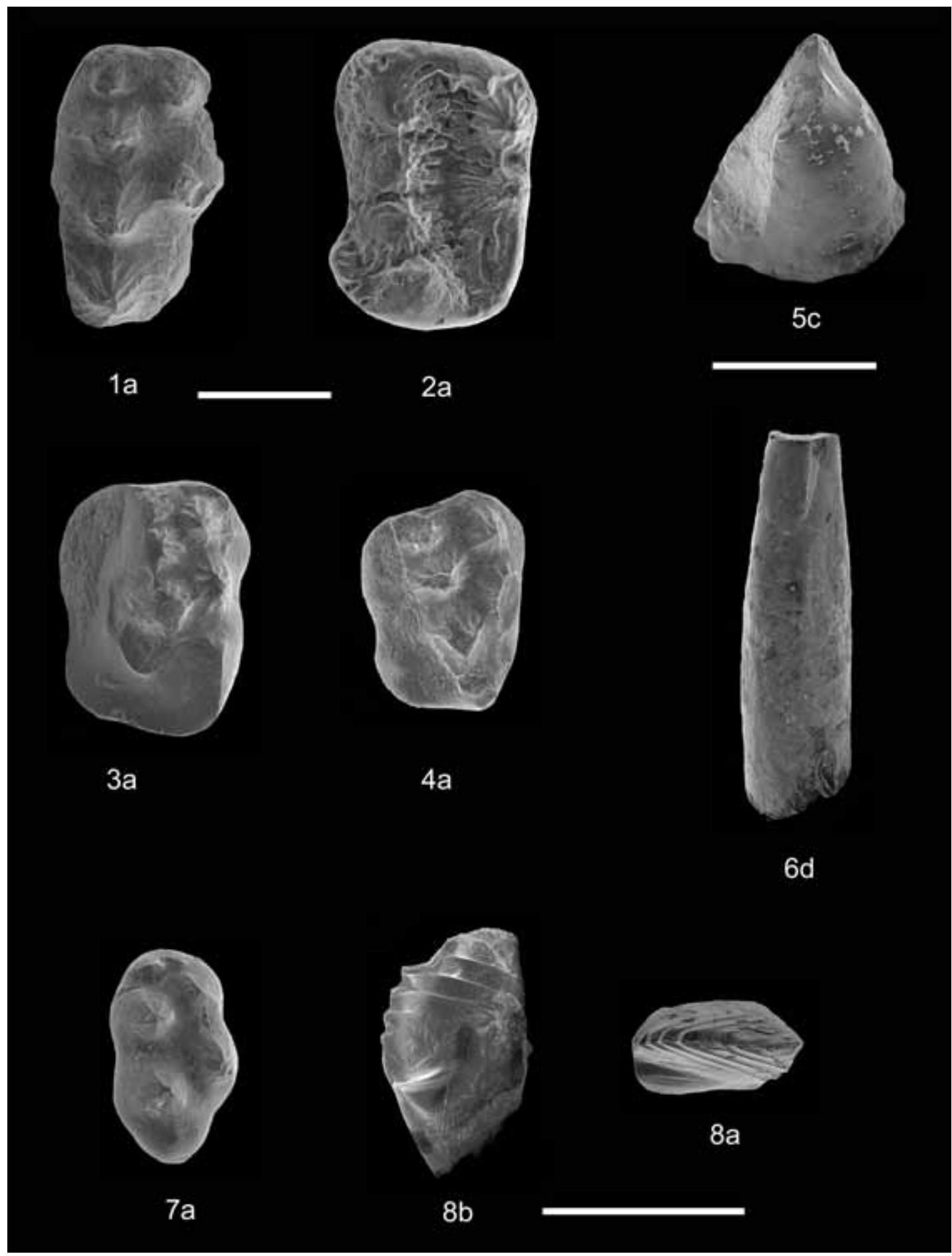

Fig. 5.- Scanning electron micrographs of gold-palladium-coated teeth of multituberculates from the La Cantalera site (late Hauterivianearly Barremian, Teruel, Spain). 1-2) Cantalera abadi, (1) left P4/5, paratype (CAN/934), (2) left M1, holotype (CAN 1/1609). 3-4) Eobaatar sp., (3) left P5 with severe wear on the lingual and distal margins of the crown (CAN 1/1611), (4) left P5 (CAN 1/935). 5-6) "Plagiaulacida" indet., (5) fragment of an I2 (CAN 1/939), (6) fragment of a ?ix (CAN 1/938). 7-8) Plagiaulacidae or Eobaataridae gen. et sp. indet., (7) left P1/3 (CAN 1/936), (8) fragment of a right p4 (CAN 1/937). (a) occlusal; (b) labial; (c) disto-lateral; and (d) mesiolateral views. The scale bar is $1 \mathrm{~mm}$. Modified from Badiola et al. (2008).

Fig. 5.- Microfotografías de Microscopio Electrónico de Barrido de dientes recubiertos de una película de oro-paladio de multituberculados del Hauteriviense superior - Barremiense inferior del yacimiento de la Cantalera (Teruel, España). 1-2) Cantalera abadi, (1) P4/5 izquierdo, paratipo (CAN/934), (2) M1 izquierdo, holotipo (CAN 1/1609). 3-4) Eobaatar sp., (3) P5 izquierdo con un desgaste importante en los margenes linguales y distales de la corona (CAN 1/1611), (4) P5 izquierdo (CAN 1/935). "Plagiaulacida" indet. (5) fragmento de un I2 (CAN 1/939), (6) fragmento de un ?ix (CAN 1/938). 7-8) Plagiaulacidae o Eobaataridae gen. et sp. indet. (7) P1/3 izquierdo (CAN 1/936), (8) fragmento de un p4 derecho (CAN 1/937). (a) vista oclusal; (b) vista labial; (c) vista disto-lateral; (d) vista mesio-lateral. La escala es $1 \mathrm{~mm}$. Modificado de Badiola et al. (2008). 


\subsection{Eggshells}

Most of the fossil eggshells recovered from the site of $\mathrm{La}$ Cantalera come from the screen-washing. Sieving the concentrates has made it possible to recover more than 3,000 fragments of eggshell. A total of nine ootaxa have been identified, included in the oofamilies Elongaloolithidae, Prismatoolithidae, Spheroolithidae Zhao and Krokolithidae Kohring and Hirsch (Table 2).

\begin{tabular}{ll}
\hline Oofamily & Ootaxa \\
\hline Elongaloolithidae & $\begin{array}{l}\text { Elongaloolithidae indet. } \\
\text { Macroolithus turolensis Amo et al. (2000) } \\
\text { Prismatoolithidae }\end{array}$ \\
Prismatoolithus sp. \\
Prismatoolithidae indet. \\
cf. Spheroolithidae indet. 1 \\
cf. Spheroolithidae indet. 2 \\
Krokolithidae \\
Incertidae sedis & $\begin{array}{l}\text { Incertae oofamily 1 } \\
\text { Incertae oofamily 2 }\end{array}$ \\
\hline
\end{tabular}

Table 2.- Eggshell ootaxa of Parasystem Veterovata (sensu Mikhailov et al. 1996) of La Cantalera (Josa, Teruel, Spain), late Hauterivian early Barremian.

Tabla 2.- Lista de los ootaxones de cáscaras de huevo del Parasistema Veterovata (sensu Mikhailov et al. 1996) identificadas en el yacimiento de La Cantalera (Josa, Teruel, España), Hauteriviense superior - Barremiense inferior.

Elongaloolithidae is represented by Macroolithus turolensis (Fig. 6.1) and Elongaloolithidae indet. (Fig. 6.2). The eggshells in this oofamily display the ratite morphotype, with two layers of different ultrastructure and an abrupt transition between them. M. turolensis is a very abundant ootaxon, exclusive to the Hauterivian-Barremian transition of the Iberian Range (Amo-Sanjuan et al. 2000, Moreno-Azanza et al. 2008). It displays characteristic ornamentation that varies from linearituberculate to sagenotuberculate, and its maximum thickness is $1,200 \mu \mathrm{m}$. The eggshells assigned to Elongaloolithidae indet. are less thick $(450 \mu \mathrm{m})$. The external ornamentation is sagenotuberculate, but much finer than in M. turolensis.

Prismatoolithidae is represented by Prismatoolithus sp. (Fig. 6.3) and Prismatoolithidae indet. (Fig. 6.4) The shells of this oofamily are characterized by having two layers of different ultrastructure separated by a diffuse limit. Prismatoolithus sp. comprises smooth eggshells with a thickness of $400 \mu \mathrm{m}$. Prismatoolithidae indet. comprises shells with a thickness of $700 \mu \mathrm{m}$, with compactituberculate ornamentation (infrequent in this oofamily) formed by nodes with a characteristic triangular shape (Moreno-Azanza et al. 2009a). These eggshells belong to a new oogenus yet to be described.
Spheroolithidae is poorly represented by about ten eggshell fragments. These fragments have been provisionally separated into cf. Spheroolithidae indet. 1 and 2. The shells included in cf. Spheroolithidae indet. 1 (Fig. 6.6) display a prolatospherulitic morphotype, with dispersituberculate ornamentation and a thickness of roughly $420 \mu \mathrm{m}$. Those included in cf. Spheroolithidae indet. 2 (Fig. 6.5) display a prolatospherulitic morphotype, with sagenotuberculate ornamentation and a thickness of $800 \mu \mathrm{m}$. Variations in thickness and ornamentation pattern have been described in Spheroolithidae within the same ootaxon, even in the same egg (Mikhailov, 1994). Accordingly, these two morphotypes could belong to the same ootaxon.

Krokolithidae is represented by Krokolithes sp. (Fig. 6.7). This ootaxon presents shells that are $300 \mu \mathrm{m}$ in thickness, with an undulating surface and shell units with a tabular ultrastructure that are wider than high and have a characteristic trapezoidal shape. In some specimens, moreover, an external layer can be made out, also with a tabular structure and an average thickness of $25 \mu \mathrm{m}$.

The Testudoolithidae oofamily has been previously reported from La Cantalera (Moreno-Azanza et al. 2009b). Eggshells which were included in this oofamily are represented by two ootaxa (Fig. 6.8 and 6.9). The eggshells of this oofamily are 400-700 $\mu \mathrm{m}$ thick, and present singular, mushroom-shaped shell units. They are extremely porous and cannot be assigned to any of the oogenera described. The two ootaxa differ from one another in their distribution pattern and the shape of the pore-openings, as well as in their ornamentation. The former assignation to Testudoolithidae was based on the description by Kohring (1990) of similar eggshells in the Galve sub-basin. Ensom (2002) found similar eggshells in the Purbeck of Southern England and refers to the Galve eggshells as Dendroolithidae (sensu Zhao and Li, 1988) on the basis of a personal communication from Kohring. Energy-dispersive X-ray spectroscopy (EDS), electron back-scatter diffraction (EBSD) and cathodoluminescence (CL) analyses carried out on the La Cantalera eggshells confirmed the original calcite composition of these eggshells, making it possible to rule out turtle affinities. Nevertheless, Dendroolithidae is characterized by having "pore" cavities within the shell units, a feature not present either in the La Cantalera or the Galve eggshells. Furthermore, the absence of preserved organic cores in the over 80 eggshells recovered from La Cantalera makes it impossible to be sure that they are dinosaur eggshells, as crocodiloid affinities cannot be discarded. These eggshells are currently under study, and new analyses may help to elucidate the nature of them, but at this point of the study they are referred to as oofamily incertidae sedis 1 and 2. 


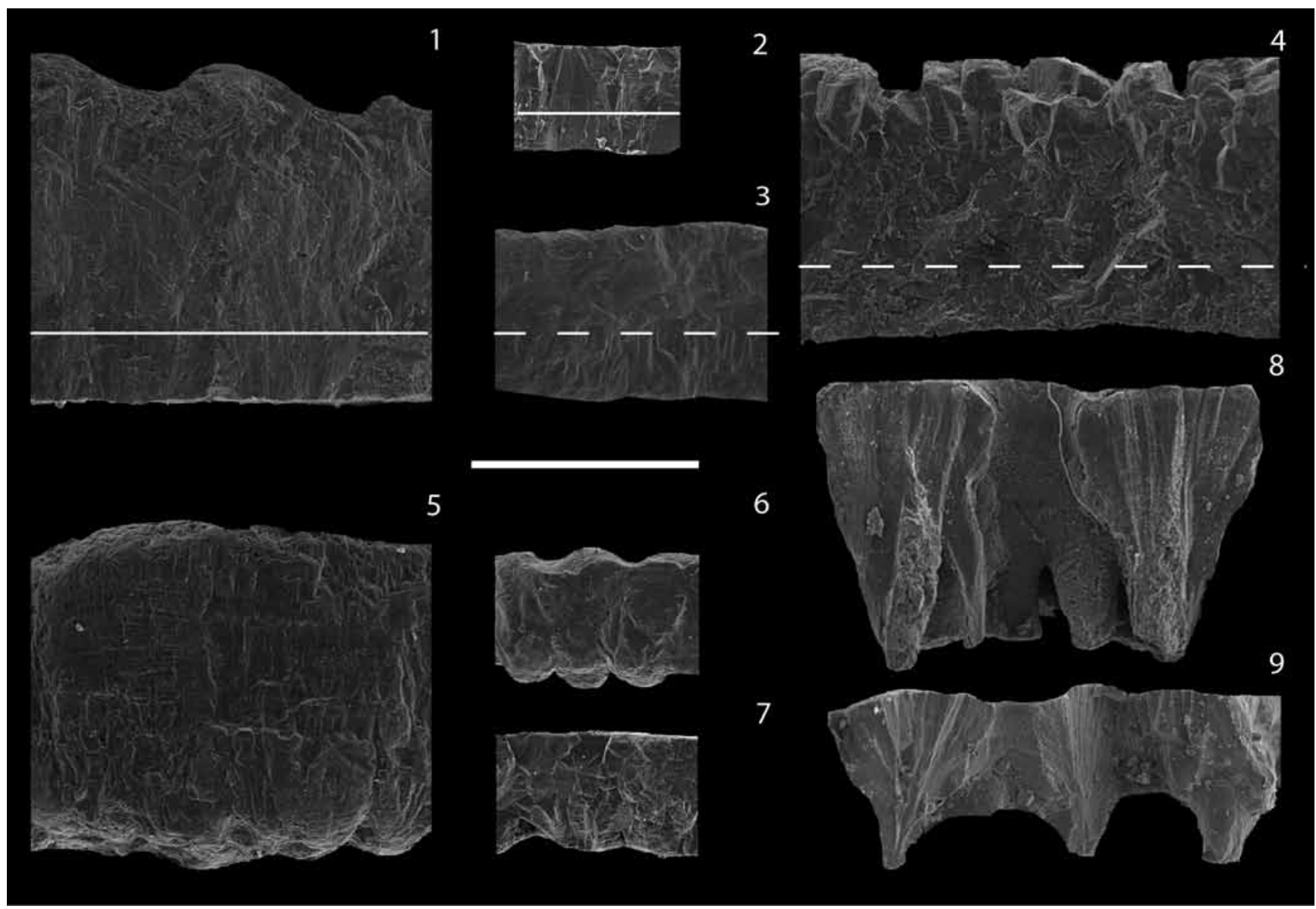

Fig. 6.- Eggshells from La Cantalera Site. Scanning electron micrographs of gold-palladium-coated radial sections. 1) Macroolithus turolensis (CAN1-1617). 2) Elongaloolithidae indet. (CAN1-1618). 3) Prismatoolithus sp. (CAN1-1619). 4) Prismatoolithidae indet. (CAN1-1620). 5) cf. Spheroolithidae indet. 2 (CAN1-1621). 6) cf. Spheroolithidae indet. 1 (CAN1-1622). 7) Krokolithes sp. (CAN11623). 8) Oofamily incertidae sedis 1 (CAN1-1624). 9) Oofamily incertidae sedis 2 (CAN1-1625). Solid lines indicate discrete transitions between mammiliare and prismatic layers. Dashed lines indicate approximate position of the continuous transition between mammilare and prismatic layers. The scale bar is $500 \mu \mathrm{m}$.

Fig. 6.- Cáscaras de huevo del yacimiento de La Cantalera. Microfotografías de Microscopio Electrónico de Barrido de secciones radiales recubiertas con oro-paladio. 1) Macroolithus turolensis (CAN1-1617). 2) Elongaloolithidae indet. (CAN1-1618). 3) Prismatoolithus sp. (CAN1-1619). 4) Prismatoolithidae indet. (CAN1-1620). 5) cf. Spheroolithidae indet. 2 (CAN1-1621). 6) cf. Spheroolithidae indet. 1 (CAN1-1622). 7) Krokolithes sp. (CAN1-1623). 8) Oofamilia incertidae sedis 1 (CAN1-1624). 9) Oofamilia incertidae sedis 2 (CAN11625). Las líneas continuas indican la transición entre la capa mamilar y la capa prismática. Las líneas discontinuas señalan la posición aproximada de la transición progresiva entre ambas capas. La escala es $500 \mu \mathrm{m}$.

The eggshell association displays significant differences with respect to the association of skeletal and tooth remains. This can be explained by the fact that only some of the taxa that visited or lived at La Cantalera laid eggs in their surroundings. The shells associated with theropod dinosaurs (the oofamilies Elongaloolithidae and Prismatoolithidae) are the most diverse, in concordance with the great diversity of theropod teeth present at the site. Significant is the great scarcity of shells associated with ornithopod dinosaurs (the oofamily Spheroolithidae), teeth of which are very abundant at the site. Also surprising is that there is only one type of crocodile shell (Krokolithidae), when at least four distinct taxa can be identified at La Cantalera. Here it should be pointed out that the structure of crocodile eggshells is very conservative, and the same ootaxon may be present in different species.

\section{Discussion and Conclusions}

The vertebrate association of La Cantalera provides a good example of a continental biota of the HauterivianBarremian of the Iberian Peninsula. The highly diverse vertebrate fossils are composed mainly of isolated teeth, disarticulated, complete or fragmented bones, eggshell fragments, and coprolites. To date, 31 different vertebrate taxa have been identified (Table 1). The material is generally too fragmentary to permit classification to species level, but it allows us to establish the main groups repre- 
sented at the site and the minimum number of taxa that lived at or in the vicinity of La Cantalera. The accumulation provides a good representation of the vertebrates in the surrounding area. This can be deduced partially on the basis of geological criteria; for La Cantalera is a small basin where fluvial sediments are lacking. There is not significative evidence of allochtonous continental sediments in the Cantalera basin. Most of the bone, tooth and eggshell fragments show no evidence of transport. As noted above, the site has a complex taphonomic history, a result of the vital activity of the vertebrates (shed teeth), the accumulation of carcasses in situ, and the action of predators and/or scavengers. The afore-mentioned taphonomic evidence suggests that the fossil association of $\mathrm{La}$ Cantalera reflects a significant part of the biodiversity of a lentic ecosystem and not a taphonomic accumulation produced by transport from different ecosystems at a distance from where the site was formed.

The transition between the Hauterivian and the Barremian of the Iberian Range in Teruel is a singularly rich period in terms of vertebrate remains. Many of the sites are located in the upper part of the El Castellar Formation, which outcrops magnificently in the municipality of Galve (Ruiz-Omeñaca et al., 2004). The sites of the El Castellar Formation were deposited in a lacustrine environment with a constant body of water and a possible marine influence (Diaz Molina and Yébenes, 1987; Soria de Miguel, 1997). There are significant differences between the fossil association of the upper part of the El Castellar Formation and La Cantalera, which can be explained in terms of the different palaeoenvironments represented. In the first place, the complete absence of Chondrichthyes and the almost complete absence of Osteichthyes in La Cantalera can be well explained in terms of it being a marshy environment that periodically dried up (Aurell et al., 2004). In the El Castellar Formation, by contrast, these two groups of pisciforms are very abundant and diverse, and their teeth are the main component of all the sites studied (Estes and Sanchiz, 1982b; RuizOmeñaca et al., 2004). Chelonian remains are among the most abundant of any tetrapod in the El Castellar Formation, whereas at La Cantalera their record is merely nominal and comprises just a single taxon. Another significant difference is in the mammal association, which in the El Castellar Formation is made up of eupantotherians (Canudo and Cuenca, 1996), whereas at La Cantalera only multituberculates are represented (Badiola et al., 2008). Less evident are the differences between the dinosaurs, though some can be pointed out. There is greater sauropod diversity in the El Castellar Formation (Sanz et al., 1987; Ruiz-Omeñaca, 2006; Royo-Torres and Cobos, 2007) than at La Cantalera, where only one taxon is represented (Canudo et al., 2002b). By contrast, theropod diversity is greater at La Cantalera. The intensive work that is being carried out in the prospection of this geological interval will confirm whether these differences are of a palaeoecological nature or the result of a taphonomic bias.

\section{Acknowledgements}

This paper forms part of the project CGL2007-62469, subsidized by the Ministry of Science and Innovation, the European Regional Development Fund, the Government of Aragon ("Grupos Consolidados" and "Dirección General de Patrimonio Cultural") and the Government of the Principality of Asturias (Protocol CN-04-226; JIR-O). Miguel Moreno, Daniel Daniel Gómez-Fernández and Ainara Badiola also acknowledge support from the Ministry of Science and Innovation (FPI BES-2008-005538), the Instituto de Estudios Turolenses (IET) and the Juan de la Cierva Program of the Ministry of Education and Science, respectively. The corrections of Oliver Rauhut and Angela Buscalioni substantially improved the original manuscript. Rupert Glasgow translated to the text into English.

\section{References}

Amo Sanjuán, O., Canudo, J.I., Cuenca-Bescós, G. (2000): First record of elongatoolithid eggshells from the Lower Barremian (Lower Cretaceous) of Europe (Cuesta Corrales 2, Galve Basin, Teruel, Spain). In: A. M Bravo, T. Reyes (eds.), First International Symposium on Dinosaur Eggs and Babies. Extendend Abstracts, Isona i Conca Dellà: 7-14.

Aurell, M., Bádenas, B., Casas, A., Alberto, S. (2001): La Geología del Parque Cultural del Río Martín. Colección Parque Cultural del Río Martín, Zaragoza: 171 p.

Aurell, M., Bádenas, B., Canudo, J. I., Ruiz-Omeñaca, J. I. (2004): Evolución tectosedimentaria de la Fm. Blesa (Cretácico Inferior) en el entorno del yacimiento de vertebrados de la Cantalera (Josa, Teruel). Geogaceta, 35: 11-13.

Badiola, A., Canudo, J. I., Cuenca-Bescós, G. (2008): New multituberculate mammals from the Hauterivian-Barremian transition of Europe (Iberian Peninsula). Palaeontology, 51: 1455-1469 [Corrigendum, Vol. 52, 2009: 271]. http://dx.doi. org/10.1111/j.1475-4983.2008.00822.x

Badiola, A., Canudo, J. I., Cuenca-Bescós, G. (2009): New Early Cretaceous multituberculate fossils from the Iberian Peninsula. Tribute to Charles Darwin and Bernissart Iguanodons: New Perspectives on Vertebrate Evolution and Early Cretaceous Ecosystems, Brussels. Programme, Abstracts and Field Trips Guidebook: p. 16.

Báez, A. M., Sanchiz, B. (2007): A review of Neusibatrachus wilferti, an Early Cretaceous frog from the Montsec Range, northeastern Spain. Acta Palaeontologica Polonica, 52 (3): 477-487.

Benson, B. J., Carrano, M. T., Brusatte, S. L. (2010): A new clade of archaic large-bodied predatory dinosaurs (Theropoda: Allo- 
sauroidea) that survived to the latest Mesozoic. Naturwissenschaften, 97: 71-78. http://dx.doi.org/10.1007/s00114-009$\underline{0614-x}$

Brinkmann, W. (1992): Die Krokodilier-Fauna aus der UnterKreide (Ober- Barremium) von Uña (Provinz Cuenca, Spanien). Berliner Geowissenschaftliche Abhandlungen E, 5: 1-123.

Brusatte, S. L., Benson, R. B., Carr, T. D., Williamson, T. E., Sereno, P. (2007): The systematic utility of theropod enamel wrinkles. Journal of Vertebrate Paleontology, 27: 1052-1056. http://dx.doi.org/10.1671/0272-4634(2007)27[1052:TSUOT E]2.0.CO;2

Brusatte, S. L., Sereno, P. (2008): Phylogeny of Allosauroidea (Dinosauria: Theropoda): comparative analysis and resolution. Journal of Systematic Palaeontology: 155-182. http://dx.doi. org/10.1017/S1477201907002404

Buscalioni, A. D., Fregenal, M. A., Bravo, A., Poyato-Ariza, F. J., Sanchiz, B., Báez, A. M., Cambra Moo, O., Martín Closas, C., Evans, S. E., Marugan Lobón, J. (2008): The vertebrate assemblage of Buenache de la Sierra (Upper Barremian of Serrania de Cuenca, Spain) with insights into its taphonomy and palaeocology. Cretaceous Research, 29: 687-710. http://dx.doi. org/10.1016/j.cretres.2008.02.004

Buscalioni, A., Sanz, J. L. (1984): Los arcosaurios (Reptilia) del Jurásico superior-Cretácico inferior de Galve (Teruel, España). Teruel, 71: 9-30.

Buscalioni, A. D., Sanz, J. L. (1987): Cocodrilos del Cretácico inferior de Galve (Teruel, España). Estudios Geológicos, volumen extraordinario Galve-Tremp: 23-43.

Buscalioni, A., Sanz, J. L. (1990): The small crocodile Bernissartia fagesii from the Lower Cretaceous of Galve (Teruel, Spain). Bulletin de l'Institut Royal des Sciences naturelles de Belgique, 60: $129-150$.

Canale, J. I., Scanferia, C. A., Agnolin, F. L., Novas, F. E. (2008): New carnivorous dinosaur from the Late Cretaceous of NW Patagonia and the evolution of abelisaurid theropods. Naturwissenschaften, 96: 409-414. http://dx.doi.org/10.1007/s00114008-0487-4

Canudo, J. I. (2006): La ambigüedad paleobiogeográfica de los dinosaurios ibéricos durante el Cretácico Inferior. In: CAS (ed.), Actas de las III Jornadas Internacionales sobre Paleontología de Dinosaurios y su Entorno. Salas de los Infantes: 21-45.

Canudo, J. I., Aurell, M., Barco, J. L., Cobos, A., Cuenca-Bescós, G., Martín-Closas, C., Murelaga, X., Pereda-Suberbiola, X., Royo-Torres, R., Ruiz-Omeñaca, J. I. (2002a): La Cantalera: Un resumen de los dinosaurios del tránsito Hauteriviense - Barremiense (Cretácico inferior) de la Cordillera Ibérica (Josa, Teruel). XVIII Jornadas de la Sociedad Española de Paleontología, Salamanca: pp. 27-28.

Canudo, J. I., Barco, J. L., Pereda-Suberbiola, X., Ruiz-Omeñaca, J. I., Salgado, L., Torcida Fernández-Baldor, F., Gasulla, J. M. (2009): What Iberian dinosaurs reveal about the bridge said to exist between Gondwana and Laurasia in the Early Cretaceous. Bulletin de la Société Géologique de France, 180: 5-11. http:// dx.doi.org/10.2113/gssgfbull.180.1.5

Canudo J. I., Cuenca G. (1996): Two new mammalian teeth (Multituberculata and Peramura) from Lower Cretaceous (Barremian) of Spain. Cretaceous Research, 17: 215-228. http:// dx.doi.org/10.1006/cres.1996.0016

Canudo, J. I., Gasulla, J. M., Gómez-Fernández, D., Ortega, F., Sanz, J. L., Yagüe, P. (2008a): Primera evidencia de dientes aislados atribuidos a Spinosauridae (Theropoda) en el Aptiano inferior (Cretácico Inferior) de Europa: Formación Arcillas de Morella (España). Ameghiniana, 45: 649-652.

Canudo, J. I., Royo-Torres, R., Cuenca-Bescós, G. (2008b): A new sauropod: Tastavinsaurus sanzi gen. et sp. nov. from the Early Cretaceous (Aptian) of Spain. Journal of Vertebrate Paleontology, 28: 712-731. http://dx.doi.org/10.1671/02724634(2008)28[712:ANSTSG]2.0.CO;2

Canudo, J. I., Ruiz-Omeñaca, J. I., Barco, J. L., Royo-Torres, R. (2002b): ¿Saurópodos asiáticos en el Barremiense inferior (Cretácico Inferior) de España? Ameghiniana, 34: 443-452.

Canudo, J. I., Ruiz-Omeñaca, J. I., Cuenca-Bescós, G. (2004): Los primeros dientes de anquilosaurio (Ornithischia: Thyreophora) descritos en el Cretácico Inferior de España. Revista Española de Paleontología, 19: 33-46.

Costa, O. G. (1864): Paleontologia del Regno di Napoli, III. Atti Accademia Pontaniana, Napoli, 8: 1-198.

Cuenca-Bescós, G., Canudo, J. I. (2003): A new gobiconodontid mammal from the Early Cretaceous of Spain and its palaeobiogeographical implications. Acta Palaeontologica Polonica, 48: 575-582.

Díaz Molina, M., Yébenes, A. (1987): La sedimentación litoral y continental durante el Cretácico Inferior. Sinclinal de Galve, Teruel. Estudios Geológicos, volumen extraordinario GalveTremp: 3-21. http://dx.doi.org/10.3989/egeol.8743Extra623

Estes, R., Sanchiz, B. (1982a): New discoglossid and palaeobatrachid frogs from the Late Cretaceous of Wyoming and Montana, and a review of other frogs from the Lance and Hell Creek formations. Journal of Vertebrate Paleontology, 2: 9-20. http:// dx.doi.org/10.1080/02724634.1982.10011914

Estes, R., Sanchiz, F. (1982b): Early Cretaceous lower vertebrates from Galve (Teruel), Spain. Journal of Vertebrate Paleontology, 2: 21-39. http://dx.doi.org/10.1080/02724634.1982.10011915

Ensom, P. C. (2002): Reptile eggshell, tiny vertebrate remains and globular calcified cartilage from the Purbeck Limestone Group of Southern England. Special Papers in Palaeontology, 68: 221-239.

Fey, B. 1988. Die Anurenfauna aus der Unterkreide von Uña (Ostspanien). Berliner Geowissenschaftliche Abhandlungen (Reihe A), 103: 1-99.

Folie, A. L., Codrea, V. (2005): New lissamphibians and squamates from the Maastrichtian of Hateg Basin, Romania. Acta Palaeontologica Polonica, 50: 57-71.

Galton, P. M. (1974): The ornithischian dinosaur Hypsilophodon from the Wealden of the Isle of Wight. Bulletin of The British Museum (Natural History) Geology, 25: 1-152.

Gardner, J. D., Böhme, M. (2008): Review of the Albanerpetontidae (Lissamphibia), with Comments on the Paleoecological Preferences of European Tertiary Albanerpetontids. In: S. T. Sankey, S. Baszio, S. (eds.), Vertebrate Microfossil Assemblages. Their Role in Paleoecology and Paleobiogeography. Indiana University Press, Bloomington: 178-218.

Gardner, J. D., Evans, S. E., Sigogneau-Russell, D. (2003): New albanerpetontid amphibians from the Early Cretaceous of Morocco and Middle Jurassic of England. Acta Palaeontologica Polonica, 48: 301-319.

Gasca, J. M., Gómez-Fernández, D., Moreno-Azanza, M., Canudo, J. I. (2009): Un paseo por los yacimientos del tránsito Hauteriviense - Barremiense (Cretácico Inferior) de Aragón. Paleolusitana, 1: 211-219. 
Godefroit, P., Li, H., Shang, C.-Y. (2005): A new primitive hadrosauroid dinosaur from the Early Cretaceous of Inner Mongolia (P. R. China). Comptes Rendus Palevol, 4: 697-705. http:// dx.doi.org/10.1016/j.crpv.2005.07.004

Gómez-Fernández, D., Canudo, J. I. (2010): Dientes de terópodos del tránsito Hauteriviense-Barremiense (Cretácico Inferior) en La Cantalera (Josa, Teruel). Teruel. (in press)

Grambast, L. (1968): Evolution of the utricule in the Charophyte genera Perimneste Harris and Atopochara Peck. Journal of the Linnean Society of London (Botany), 61: 5-11. http://dx.doi. org/10.1111/j.1095-8339.1968.tb00099.x

Hossini S. (1992) : Les Anoures (Amphibiens) de l'Oligocène terminal et du Miocène français. Doctoral Dissertation, Université de Paris, Paris, France (unpublished).

Kielan-Jaworowska, Z., Dashzeveg, D., Trofimov, B. A. (1987): Early Cretaceous multituberculates from Mongolia and a comparison with the Late Jurassic forms. Acta Palaeontologica Polonica, 32: 3-47.

Kirkland, J. I. (1998): A Polacanthine ankylosaur (Ornithischia: Dinosauria) from the Early Cretaceous (Barremian) of eastern Utah. Lower and Middle Cretaceous Terrestrial Ecosystems. New Mexico Museum of Natural History and Science, 14: 270281.

Kohring, R. (1990): Fossile Reptil-Eirschalen (Chelonia, Crocodilia, Dinosauria) aus dem unterem Barremium von Galve (provinz Teruel, SE Spanien). Paläontologische Zeitschrift, 64: 392-344.

Martill, D. M., Hutt, S. (1996): Possible baryonychid dinosaur teeth from the Wessex Formation (Lower Cretaceous, Barremian) of the Isle of Wight, England. Proceedings of the Geologists' Association, 107: 81-84. http://dx.doi.org/10.1016/ $\underline{\mathrm{S} 0016-7878(96) 80001-0}$

McGowan, G. J. (2002): Albanerpetontid amphibians from the Early Cretaceous of Spain and Italy: a description and reconsideration of their systematics. Zoological Journal of the Linnean Society, 135: 1-32. http://dx.doi.org/10.1046/j.10963642.2002.00013.x

Mikhailov, K. E. (1994): Eggs of sauropod and ornithopod dinosaurs from the Cretaceous deposits of Mongolia. Paleontologicheskii Zhurnal, 28: 141-159.

Mikhailov, K. E., Bray, E. S., Hirsch, K. F. 1996. Parataxonomy of fossil egg remains (Veterovata); principles and applications. Journal of Vertebrate Paleontology, 16, 763-769. http://dx.doi.org/10.1080/02724634.1996.10011364

Moreno-Azanza, M., Gasca, J. M., Canudo, J. I. (2008): Macroolithus turolensis como fósil guía para el Hauteriviense superiorBarremiense basal de Teruel. Libro de resúmenes XXIV Jornadas de la Sociedad Española de Paleontología, Colunga: pp. 43-44.

Moreno-Azanza, M., Gasca, J. M., Canudo, J. I. (2009a): Bizarre prismatoolithid eggshells from the Lower Cretaceous of the Iberian Range. Symposium on Dinosaur eggs and babies, Montana: p. 26.

Moreno-Azanza, M., Gasca, J. M., Canudo, J. I. (2009b): A highdiversity eggshell locality from the Hauterivian-Barremian transition of the Iberia Peninsula. Journal of Vertebrate Paleontology, 29, supplement to number 3: p. 151A.

Norman, D. B. (1986): On the anatomy of Iguanodon atherfieldensis (Ornithischia: Ornithopoda). Bulletin de l'Institut Royal des Sciences Naturelles de Belgique Sciences de la Terre, 56: 281-372.

Norman, D. B. (2002): On Asian ornithopods (Dinosauria: Ornithischia). 4. Probactrosaurus Rozhdestvensky, 1966. Zoological Journal of the Linnean Society, 136: 113-144. http://dx.doi. org/10.1046/j.1096-3642.2002.00027.x

Norman, D. B. (2004): Basal Iguanodontia. In: D. B. Weishampel, P. Dodson, H. Osmólska (eds.), The Dinosauria, University of California Press, Berkeley: 413-437.

Norman, D. B., Sues, H.-D., Witmer, L. M., Coria, R. A. (2004): Basal Ornithopoda. In: D. B. Weishampel, P. Dodson, H. Osmólska (eds.), The Dinosauria, University of California Press, Berkeley: 393-412.

Novas, F., de Valais, S., Vickers-Rich, P., Rich, T. (2005): A large Cretaceous theropod from Patagonia, and the evolution of carcharodontosaurids. Naturwissenschaften, 95: 226-230. http:// dx.doi.org/10.1007/s00114-005-0623-3

Ortega, F. (2004): Historia evolutiva de los cocodrilos Mesoeucrocodylia. Doctoral Thesis, Universidad Autónoma de Madrid, Madrid, Spain: 350 p. (unpublished)

Ortega, F., Escaso, F., Gasulla, J. M., Dantas, P., Sanz, J. L. (2006): Los Dinosaurios de la Península Ibérica. Estudios Geológicos, 62: 219-240. http://dx.doi.org/10.3989/egeol.0662122

Osi, A. (2004): The first dinosaur remains from the Upper Cretaceous of Hungary (Csehbánya Formation, Bakony Mts). Geobios, 37: 749-753. http://dx.doi.org/10.1016/j.geobi$\underline{\text { os.2003.06.005 }}$

Owen, R. (1841): Report on British fossil reptiles. Report of the British Association for the Advancement of Science, 11: 60-204.

Pereda Suberbiola, X., Torcida, F., Izquierdo, L. A., Huerta, P., Montero, D., Pérez, G. (2003): First rebbachisaurid dinosaur (Sauropoda, Diplodocoidea) from the early Cretaceous of Spain: palaeobiogeographical implications. Bulletin de la Société Géologique de France, 174: 471-479. http://dx.doi. org/10.2113/174.5.471

Pereda-Suberbiola, X., Fuentes, C., Meijide, M., Meijide-Fuentes, F., Meijide-Fuentes Jr., M. (2007): New remains of the ankylosaurian dinosaur Polacanthus from the Lower Cretaceous of Soria, Spain. Cretaceous Research, 28: 583-586.

Pérez-García, A. (2009): Revisión histórica y sistemática de las primeras citas de quelonios del Cretácico español. Revista Española de Paleontología, 24: 93-104.

Pérez-Moreno, B., Sanz, J. L., Buscalioni, A. D., Moratalla, J. J., Ortega, F., Rasskin-Gutman, D. (1994): A unique multitoothed ornithomimosaur dinosaur from the Lower Cretaceous of Spain. Nature, 370: 363-367. http://dx.doi.org/10.1038/370363a0

Rauhut, O. W. M. (2002): Dinosaur teeth from the Barremian of Uña, Province of Cuenca, Spain. Cretaceous Research, 23: 255263. http://dx.doi.org/10.1006/cres.2002.1003

Richter, A. (1994a): Der problematische Lacertilier Ilerdaesaurus (Reptilia, Squamata) aus der Unter-Kreide von Uña und Galve (Spanien). Berliner geowissenschaftliche Abhandlungen Reihe E (Paläobiologie), 13: 135-161.

Richter, A. (1994b): Lacertilia aus der Unteren Kreide von Uña und Galve (Spanien) und Anoual (Marokko). Berliner geowissenschaftliche Abhandlungen Reihe E (Paläobiologie), 14: 1-147.

Royo-Torres, R., Cobos, A. (2007): Teeth of Oplosaurus armatus (Sauropoda) from El Castellar (Teruel, Spain). 5th Meeting 
of the European Association of Vertebrate Paleontologists and 12th European Workshop of Vertebrate Palaeontology. Carcassonne-Espéraza: pp. 52-55.

Ruiz-Omeñaca, J. I. (2006): Restos directos de dinosaurios (Saurischia, Ornithischia) en el Barremiense (Cretácico Inferior) de la Cordillera Ibérica en Aragón (Teruel, España). Doctoral Thesis, Universidad de Zaragoza, Zaragoza, Spain: 432 p. (unpublished, dowloadable at: http://www.aragosaurus.com/secciones/publicaciones/artic/ruizomenaca2006.pdf)

Ruiz-Omeñaca, J. I., Canudo, J. I. (2001): Dos yacimientos excepcionales con vertebrados continentales del Barremiense (Cretácico Inferior) de Teruel: Vallipón y La Cantalera. Naturaleza Aragonesa, 8: 8-17.

Ruiz-Omeñaca, J. I., Canudo, J. I. (2003): Un nuevo dinosaurio terópodo ("Prodeinodon" sp.) en el Cretácico Inferior de La Cantalera (Teruel). Geogaceta, 34: 111-114.

Ruiz-Omeñaca, J. I., Canudo, J. I., Aurell, M., Badenas, B., Cuenca-Bescós, G., Ipas, J. (2004): Estado de las investigaciones sobre los vertebrados del Jurásico superior y el Cretácico inferior de Galve (Teruel). Estudios Geológicos, 60: 179-202. http:// dx.doi.org/10.3989/egeol.04603-694

Ruiz-Omeñaca, J. I., Canudo, J. I., Barco, J. L., Royo-Torres, R. (2003): Un germen dental de saurópodo del Barremiense Inferior (Cretácico Inferior) de La Cantalera (Josa, Teruel). In: CAS (eds.), II Jornadas de Paleontología de Dinosaurios y su Entorno. Salas de los Infantes: 193-202.

Ruiz-Omeñaca, J. I., Canudo, J. I., Cruzado-Caballero, P., Infante, P., Moreno-Azanza, M. (2005): Baryonychine teeth (Theropoda: Spinosauridae) from the Lower Cretaceous of La Cantalera (Josa, NE Spain). Kaupia. Darmstädter Beiträge zur Naturgeschichte, 14: 59-63.

Ruiz-Omeñaca, J. I., Canudo, J. I., Cuenca-Bescós, G. (1997): Primera evidencia de un área de alimentación de dinosaurios herbívoros en el Cretácico Inferior de España (Teruel). Monografias de la Academia de Ciencias Exactas, Físicas, Químicas y Naturales de Zaragoza, 10: 1-48.

Ruiz-Omeñaca, J. I., Canudo, J. I., Cuenca Bescós, G. (1998): Primeros restos de reptiles voladores (Pterosauria: Pterodactyloidea) en el Barremiense superior (Cretácico Inferior) de Vallipón (Castellote, Teruel). Mas de las Matas, 17: 225-249.

Salas, R., Guimerà, J., Más, R., Martín-Closas, C., Meléndez, A., Alonso, A. (2001): Evolution of the Mesozoic central Iberian Rift System and its Cainozoic inversion (Iberian Chain). Mémoires du Muséum Nationale de l'Histoire Naturelle, 186: 145-185.

Salgado, L., Canudo, J. I., Garrido, A. C., Ruiz-Omeñaca, J. I., García, R. A., de la Fuente, M. S. Barco, J. L., Bollati, R. (2009): Upper Cretaceous vertebrates from "El Anfiteatro" (Río Negro, Patagonia, Argentina). Cretaceous Research, 30: 767-784. http://dx.doi.org/10.1016/j.cretres.2009.01.001

Sanchiz, F. B. (1977): La familia bufonidae (Amphibia, Anura) en el Terciario europeo. Trabajos sobre el Neógeno-Cuaternario, CSIC, 8: 75-111.

Sanchiz, F. B. (1998): Salientia. In: Handbuch der Paläoherpetologie, tome 4. Verlag Dr. Freidrich Pfeil, München: 275 p.

Sanz, J. L., Buscalioni, A. D., Casanovas, M. L., Santafé, J. V. (1987): Dinosaurios del Cretácico Inferior de Galve (Teruel, España). Estudios Geológicos, volumen extraordinario Galve Tremp, 45-64.
Sanz, J. L., Wenz, S., Yebenes, A., Estes, R., Martinez-Delclos, X., Jimenez-Fuentes, E., Dièguez, C., Buscalioni, A. D., Barbadillo, L. J., Via, L. (1988): An Early Cretaceous Faunal and Floral Continental Assemblage: Las Hoyas Fossil Site (Cuenca, Spain), Geobios, 21(5): 611-635. http://dx.doi.org/10.1016/ S0016-6995(88)80072-X

Seiffert, J. (1972): Ein Vorläufer der Froschfamilien Palaeobatrachidae un Ranidae im Grenzbereich Jura-Kreide. Neues Jahrbuch für Geologie und Paläontologie, 2: 120-131.

Soria de Miguel, A. R. (1997): La sedimentación en las cuencas marginales del Surco Ibérico durante el Cretácico Inferior y su contorno estructural. Doctoral Thesis, Universidad de Zaragoza, Zaragoza, Spain: 363 p.

Soria, A. R., Martín-Closas, C., Meléndez, A., Meléndez, N., Aurell, M. (1995): Estratigrafía del Cretácico inferior del sector central de la Cordillera Ibérica. Estudios Geológicos, 51: 141152. http://dx.doi.org/10.3989/egeol.95513-4292

Sweetman, S. (2009): A new species of the plagiaulacoid multituberculate mammal Eobaatar from the Early Cretaceous of southern Britain. Acta Palaeontologica Polonica, 54: 373-384. http://dx.doi.org/10.4202/app.2008.0003

Torcida Fernández-Baldor, F., Ruiz-Omeñaca, J. I., Izquierdo Montero, L. A, Montero Huerta, D, Pérez Martínez, G., Huerta Hurtado, P., Urién Montero, V. (2005): Dientes de un enigmático dinosaurio ornitópodo en el Cretácico Inferior de Burgos (España). Revista Española de Paleontología, número extraordinario, 10: 73-81.

Venczel, M., Csiki, Z. (2003): New frog from the Latest Cretaceous of Hateg Basin, Romania. Acta Palaeontologica Polonica, 48: 609-616.

Villalta, J. F. (1957): Eodiscoglossus santojae Vill., la Rana más antigua conocida, que ha sido enconrada en el Jurásico superior de Santa María de Meya (Lérida). In: B. Meléndez (ed.), La evolución biológica, Ediciones Fax, Madrid:146.

Vullo, R., Buscalioni, A., Marugán-Lobón, J., Moratalla, J. J. (2009): First pterosaur remains from the Early Cretaceous Lagerstätte of Las Hoyas, Spain: palaeoecological significance. Geological Magazine, 146: 931-936. http://dx.doi. org/10.1017/S0016756809990525

Vullo, R., Neraudeau, D., Lenglet, T. (2007): Dinosaur teeth from the Cenomanian of Charentes, Western France: evidence for a mixed laurasian-gondwanan assemblage. Journal of Vertebrate Paleontology, 27: 931-943. http://dx.doi.org/10.1671/02724634(2007)27[931:DTFTCO]2.0.CO;2

Weichmann, M. F. (2000): The albanerpetontids from the Guimarota mine. In: T. Martin, B. Krebs, (eds.), Guimarota - A Jurassic Ecosystem, Verlag Dr. Frierich Pfeil, Münich: 51-54.

Weishampel, D. B., Jianu, C. M., Csiki, Z., Norman, D. B. (2003): Osteology and phylogeny of Zalmoxes (n. g.), an unusual Euornithopod dinosaur from the latest Cretaceous of Romania. Journal of Systematic Palaeontology, 1: 85-123. http://dx.doi. org/10.1017/S1477201903001032

Wellnhofer, P. (1971): Die Atoposauridae (Crocodylia, Mesosuchia) der oberjura-Plattenkalke Bayerns. Palaeontographica Abteilung A, 138: 133-165.

Wellnhofer, P., Buffetaut, E. (1999): Pterosaur remains from the Cretaceous of Morocco. Paläontologische Zeitschrift, 73: 133-142.

Wilson, J. A., Upchurch, P. (2009): Redescription and reassessment of the phylogenetic affinities of Euhelopus zdanskyi 
(Dinosauria: Sauropoda) from the Early Cretaceous of China. Journal of Systematic Palaeontology, 7: 199-239. http://dx.doi. org/10.1017/S1477201908002691
Zhao, Z., Li, Z. (1988): A new structural type of the dinosaur eggs from Anlu County, Hubei Province. Vertebrata PalAsiatica, 26: $107-115$. 